\title{
Preparation of Antiproliferative Terpene-Alkaloid Hybrids by Free Radical-Mediated Modification of ent-Kauranic Derivatives
}

\author{
Elena Pruteanu ${ }^{1,2} \mathbb{D}^{\mathbb{D}}$, Vladilena Gîrbu ${ }^{1}(\mathbb{D})$, Nicon Ungur ${ }^{1}\left(\mathbb{D}\right.$, Leentje Persoons ${ }^{3}$, Dirk Daelemans ${ }^{3}$, \\ Philippe Renaud ${ }^{2, *(\mathbb{D})}$ and Veaceslav Kulciți ${ }^{1, * \mathbb{D}}$ \\ 1 Institute of Chemistry (MECC), Str. Academiei, 3, MD-2028 Chișinău, Moldova; \\ elena.pruteanu@unibe.ch (E.P.); vgirbu1@gmail.com (V.G.); nicon.ungur@gmail.com (N.U.) \\ 2 Department of Chemistry, Biochemistry and Pharmaceutical Sciences, University of Bern, Freiestrasse 3, \\ 3012 Bern, Switzerland \\ 3 KU Leuven, Department of Microbiology, Immunology and Transplantation, Laboratory of Virology \\ and Chemotherapy, Rega Institute for Medical Research, Herestraat 49, 3000 Leuven, Belgium; \\ leentje.persoons@rega.kuleuven.be (L.P.); dirk.daelemans@kuleuven.be (D.D.) \\ * Correspondence: philippe.renaud@unibe.ch (P.R.); kulcitki@yahoo.com (V.K.)
}

\section{check for}

updates

Citation: Pruteanu, E.; Gîrbu, V.; Ungur, N.; Persoons, L.; Daelemans, D.; Renaud, P.; Kulcițki, V.

Preparation of Antiproliferative Terpene-Alkaloid Hybrids by Free Radical-Mediated Modification of ent-Kauranic Derivatives. Molecules 2021, 26, 4549. https://doi.org/ $10.3390 /$ molecules26154549

Academic Editor: Maria José U. Ferreira

Received: 21 June 2021

Accepted: 19 July 2021

Published: 28 July 2021

Publisher's Note: MDPI stays neutral with regard to jurisdictional claims in published maps and institutional affiliations.

Copyright: (c) 2021 by the authors. Licensee MDPI, Basel, Switzerland. This article is an open access article distributed under the terms and conditions of the Creative Commons Attribution (CC BY) license (https:// creativecommons.org/licenses/by/ $4.0 /)$.

\begin{abstract}
A convenient strategy for molecular editing of available ent-kauranic natural scaffolds has been developed based on radical mediated $\mathrm{C}-\mathrm{C}$ bond formation. Iodine atom transfer radical addition (ATRA) followed by rapid ionic elimination and radical azidoalkylation were investigated. Both reactions involve radical addition to the exo-methylenic double bond of the parent substrate. Easy transformations of the obtained adducts lead to extended diterpenes of broad structural diversity and artificial diterpene-alkaloid hybrids possessing lactam and pyrrolidine pharmacophores. The cytotoxicity of selected diterpenic derivatives was examined by in vitro testing on several tumor cell lines. The terpene-alkaloid hybrids containing $N$-heterocycles with unprecedented spiro-junction have shown relevant cytotoxicity and promising selectivity indexes. These results represent a solid basis for following research on the synthesis of such derivatives based on available natural product templates.
\end{abstract}

Keywords: diterpene; ent-kaurane; alkaloids; radical chemistry; ATRA; lactam; lactone; spiro compound; azide; pyrrolidine; cytotoxicity

\section{Introduction}

The kauranic family of diterpenes is widespread in diverse plant sources and some representatives are readily available for large scale processing. The best known examples are ent-kaurenoic acid 1 and steviol 2 (Figure 1), which can be conveniently isolated from industrial crop derived products or residues. Iso-steviol 3 can also be included in this group, since it easily forms upon acidic hydrolysis of steviol $\mathbf{2}$ glycosides found in the Stevia Rebaudiana plant and is broadly used as an alternative non-caloric sweetener [1]. These compounds alone possess relevant biological activities [2-4], and numerous SAR studies have been reported based on their structural modifications [5-7]. In particular, chemical modification of steviol 2 and especially iso-steviol 3 has been well explored and delivered diverse compound libraries, basing on chemical reactivity of both carboxylic groups, as well as D-cycle functionalities [6,7].

ent-kaurenoic acid $\mathbf{1}$ has also been extensively involved in SAR studies and chemical modification was reported frequently at the level of the carboxylic functional group. The reactivity of the exo-methylenic $\Delta^{16}$-double bond was mostly addressed via the heteroatom addition processes or trivial oxidative transformations and only scarce data involve deeper skeletal modifications based on this functionality [8,9]. The exo-methylene moiety of acid 1 represents an additional opportunity for increasing molecular complexity based upon 
free radical processes. Free radical transformations are mild and versatile molecular editing tools, which have gained increasing popularity within the natural product chemistry community due to their tremendous potential for convenient late-stage functionalization of natural product scaffolds. Remote $\mathrm{C}-\mathrm{H}$ functionalization is one example [10-12]. As a logical consequence, medicinal chemistry research can fully benefit from the structural diversity generated by free radical transformations of available natural product templates.
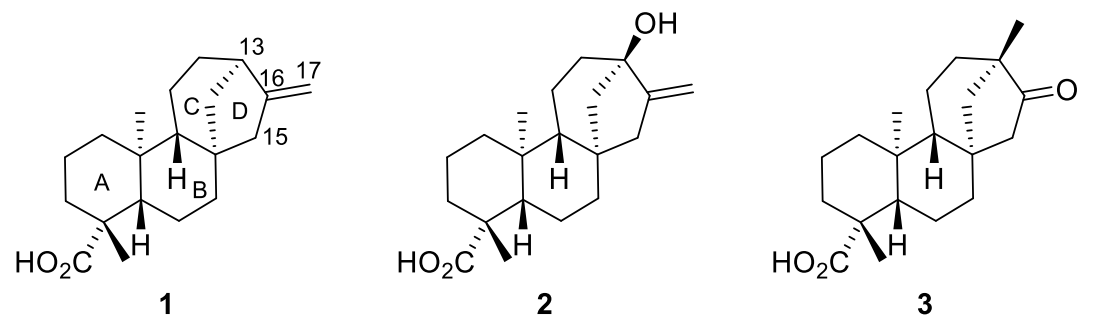

Figure 1. Structures of ent-kaurenoic acid 1, steviol 2 and iso-steviol 3.

In this context, we turned our attention to two mild free radical processes that proved efficient for the functionalization of olefinic bonds in other compound families: the atom transfer radical addition (ATRA) and the azidoalkylation reaction. ATRA are highly attractive transformations originating from the work of Kharasch, who discovered the addition of activated alkyl halides to alkenes [13-15]. This pioneering work was further refined into a valuable synthetic procedure [16] with a positive impact in diverse areas of chemistry [17]. Briefly, ATRA involves a starting alkyl halide with a weak C-X bond, which upon homolytic cleavage generates a carbon-centered radical prone to interaction with the olefinic moiety of the substrate in an addition process (Scheme 1, top). The resulting free radical abstracts the X-atom from the alkyl halide and the reaction chain perpetuates. Iodine-ATRA reactions leading to tertiary iodides are often followed by a rapid elimination of $\mathrm{HI}$ and conversion to alkenes $[18,19]$. The azidoalkylation reaction is closely related to the ATRA process but involves an extra azidating agent, usually a sulfonyl azide (Scheme 1, bottom) [20-22]. This reaction has been applied for the synthesis of several alkaloids [22-24] and its stereochemistry has been investigated in detail [25]. The formal result of both transformations is a carbo-functionalization of the alkene, including the simultaneous formation of both C-C and C-heteroatom bonds.

Such transformations are quite efficient and can be run under very mild reaction conditions, compatible with other functional groups present in the substrate. Therefore, it represents an ideal tool for molecular editing within SAR studies of complex molecules like ent-kauranes. It is worth mentioning that the exo-methylenic double bond in ent-kauranes is regarded as one of the crucial elements in the interaction with molecular targets [5] and the structural modifications of the diterpenic skeleton at the level of $C(16)-C$ (17) carbon atoms can result in new properties of the corresponding derivatives. In this respect, C (17) alkylated ent-kauranes have been sporadically isolated from natural sources. A recent example relates to helikaurolides A (4) and B (5) (Figure 2)-unprecedented ent-kauranes, prenylated at $C$ (17) with a densely functionalized sesquiterpenic unit [26]. Biogenetically, both $\mathbf{4}$ and $\mathbf{5}$ have been hypothesized based upon ent-kaurenic acid $\mathbf{1}$ alkylation with the sesquiterpenic unit. Therefore, radical C (17) alkylations represent an exact mimic of this biogenetical mechanism. Having this in mind, we report in the current paper the results of the synthesis and cytotoxic activity of new ent-kauranes based on radical additions to the exo-methylenic double bond of ent-kaurenoic acid $\mathbf{1}$ and its derivatives. 

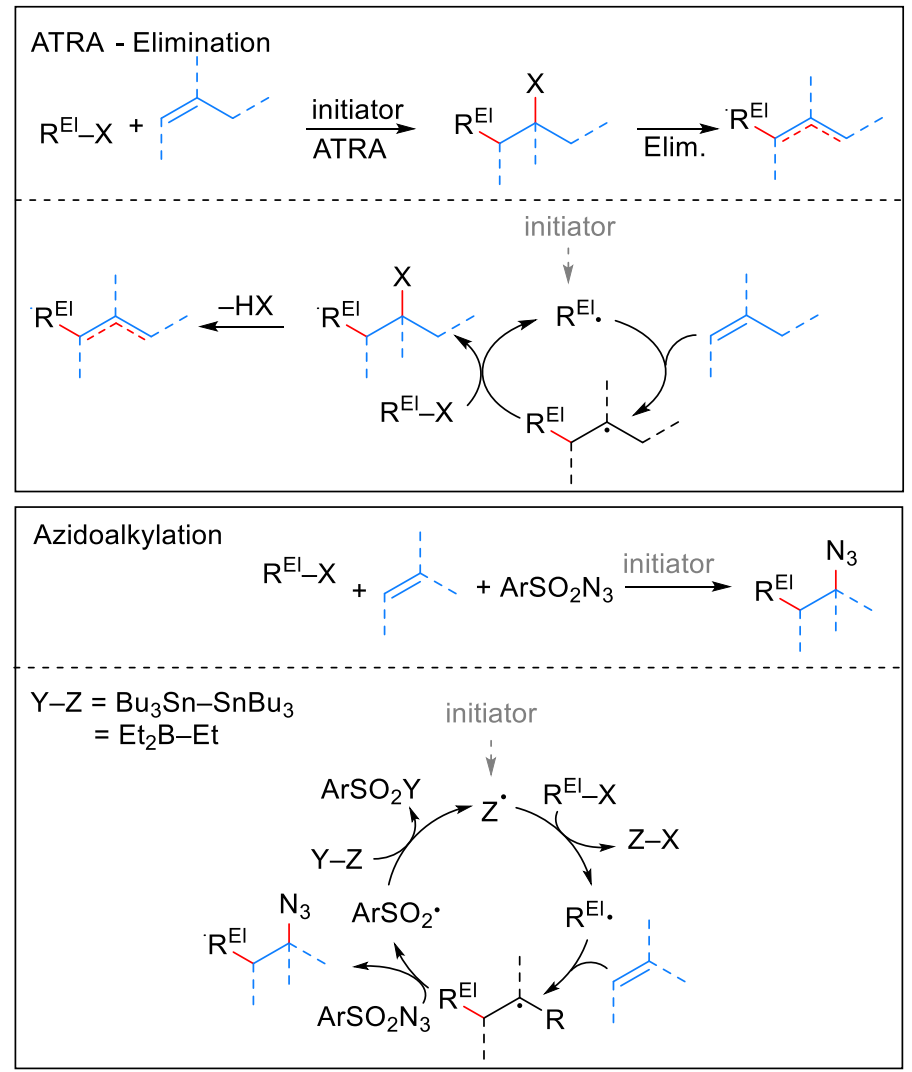

Scheme 1. Mild transformation of alkenes via ATRA (-elimination) and azidoalkylation: useful tools for molecular editing $\left(\mathrm{R}^{\mathrm{El}}=\right.$ electrophilic $\mathrm{C}$-residue $)$.

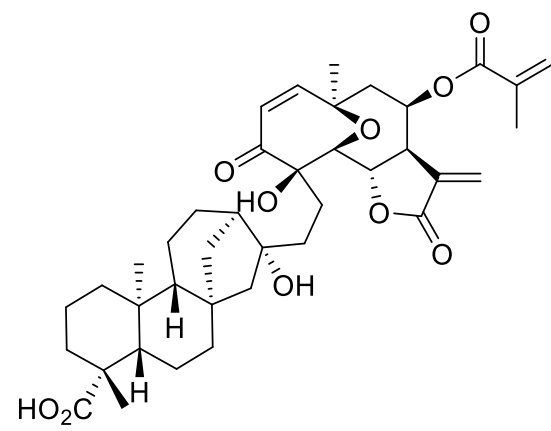

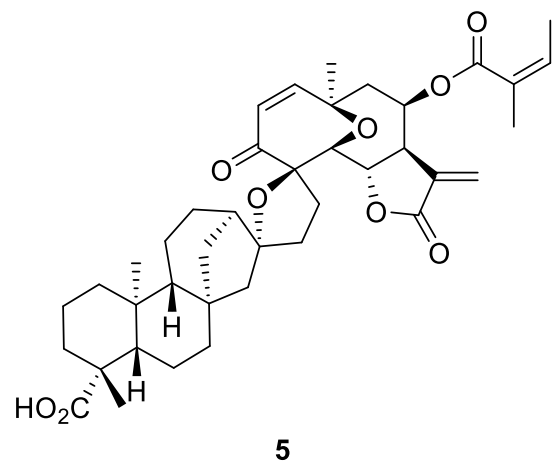

5

Figure 2. Structures of helikaurolides A (4) and B (5).

\section{Results and Discussions}

\subsection{Radical Addition to ent-Kaurenoates}

\subsubsection{Iodine-ATRA Reactions}

Carboiodination is a process that formally adds an alkyl group and an iodine atom to the olefinic moieties. It is the simplest version of ATRA, and we started our work with carboiodination of methyl ent-kaurenoate $\mathbf{6}$. It was prepared upon methylation of acid $\mathbf{1}$ with diazomethane. Ethyl iodoacetate was chosen as a readily available alkylating agent. The reaction was performed in refluxing benzene under inert atmosphere in the presence of dilauroyl peroxide (DLP) as an initiator (Scheme 2, Method A) [27].

DLP was gradually added to the reaction mixture in portions of 0.05 equivalents every $2 \mathrm{~h}$ during $24 \mathrm{~h}$ of reflux. Under these conditions, the conversion was sluggish and the starting ester $\mathbf{6}$ was recovered unchanged, along with minor amounts of esters 7-9 (15\%). Their formation can be explained by the instability of the initially formed tertiary iodide, which eliminates $\mathrm{HI}$ to provide $\mathbf{7}$ and $\mathbf{8}$. A hydrogen atom transfer, possibly involving 
DLP, can explain the formation of saturated 9. The separation of these compounds was difficult and only the endocyclic isomer 7 was isolated in a sufficiently pure form to provide satisfactory spectral data.

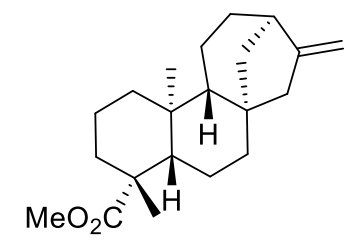

6

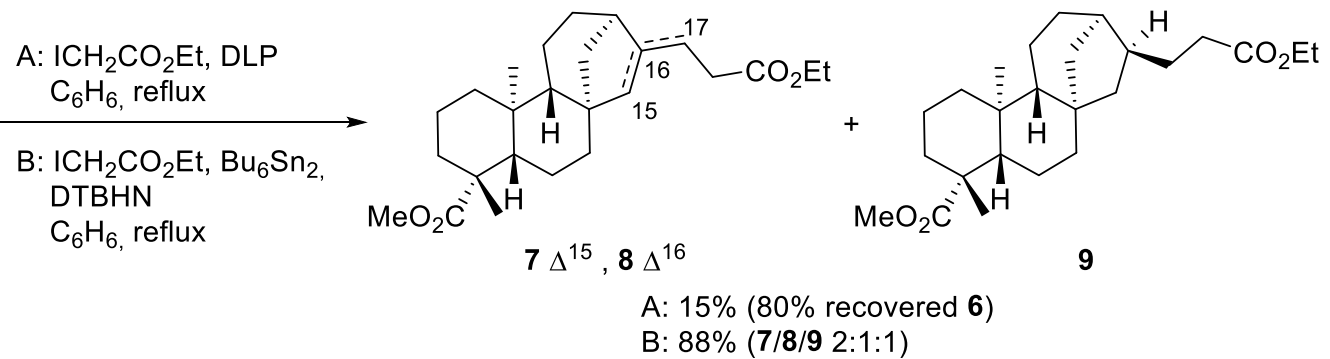

Scheme 2. Iodine-ATRA of ethyl iodoacetate to methyl-ent-kaurenoate 6.

In order to increase the conversion rate, we performed the reaction under the action of a hexabutylditin-di-tert-butyl hyponitrite (DTBHN) system, which showed good results in similar transformations [28]. The reaction resulted in the almost complete consumption of the starting material over $2 \mathrm{~h}$ at reflux and a mixture of esters 7-9 was produced with an $88 \%$ yield (Scheme 2, Method B, 7/8/9 2:1:1). The formation of the tertiary iodide was not observed. Such eliminations of tertiary iodides has been described in the literature [18].

\subsubsection{Azidoalkylation}

At this stage, it became clear that an efficient regiocontrol over $\mathrm{HI}$ elimination represents quite a challenging task for substrates with exo-methylenic double bonds. Therefore, we turned our attention to the azidoalkylation reaction, a transformation of special value from a SAR perspective due to the broad opportunities offered by the azide group for further transformation [29] such as 1,3-dipolar cycloaddition (click reaction) [30] and reduction to primary amines.

Azidoalkylation of acid 1 was performed under standard conditions using ethyl iodoacetate (radical precursor) and phenylsulfonyl azide (azidating agent) in the presence of hexabutylditin (chain transfer reagent) and DTBHN as an initiator [20]. The reaction proceeded well and the resulting azide 10 was isolated in 70\% yield (Scheme 3, Method A). The free carboxyl group remained intact. Unfortunately, the purification of the product was difficult and total removal of residual tin contaminants was not possible. In order to avoid this problem, we investigated azidoalkylation of the corresponding methyl ester 6 under the same conditions. The azide $\mathbf{1 1}$ was isolated with an $83 \%$ yield without noticeable contamination by tin residues. To avoid the use of toxic hexabutylditin, the reaction was attempted using triethylborane as a mediator [31,32]. The compatibility of triethylborane with the free carboxylic functional group of $\mathbf{1}$ was expected to be an issue [33,34]. We decided to circumvent this problem by using a two-fold excess of $\mathrm{Et}_{3} \mathrm{~B}$ and aqueous workup to hydrolyze acyloxyboron derivatives. The addition products $\mathbf{1 0}$ and $\mathbf{1 1}$ were both isolated in satisfactory $60 \%$ yields (Scheme 3, Method B).
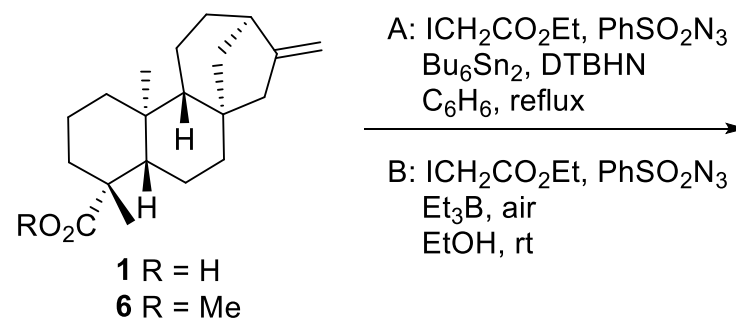

B: $\mathrm{ICH}_{2} \mathrm{CO}_{2} \mathrm{Et}, \mathrm{PhSO}_{2} \mathrm{~N}_{3}$ $\mathrm{Et}_{3} \mathrm{~B}$, air $\mathrm{EtOH}, \mathrm{rt}$

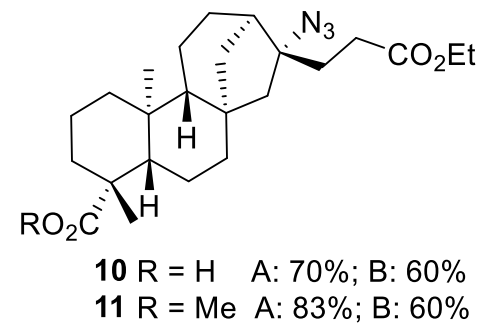

Scheme 3. Azidoalkylation of ent-kaurenoic acid $\mathbf{1}$ and methyl-ent-kaurenoate 6.

To prepare the terpene-alkaloid hybrids, the product $\gamma$-azidoester 11 was converted to $\mathrm{N}$-containg heterocycles. The hydrogenation of azide $\mathbf{1 1}$ went smoothly under 1 atmo- 
sphere of hydrogen pressure and $\mathrm{Pd} / \mathrm{C}$ as a catalyst. The initially formed primary amine spontaneously formed the lactam 12 during the reduction (Scheme 4). Further reduction of the lactam 12 with $\mathrm{NaBH}_{4} / \mathrm{I}_{2}$ furnished the pyrrolidine 13 [35]. The spiro-cyclic system in both 12 and 13 represents a novel ent-kauranic-alkaloid hybrid that turned out to be a relevant pharmacophore, as revealed by cytotoxicity testing experiments described below. The relative stereochemistry of lactam $\mathbf{1 2}$ has been determined by single crystal X-ray crystallography (Scheme 4) [36]. These data confirmed indirectly the relative stereochemistry of starting azide 11, showing that the addition of azide radicals occurred in a highly stereoselective way from the less hindered convex face of the tetracyclic ent-kauranic framework [25]. Furthermore, the ethyl ester moiety of azide $\mathbf{1 1}$ could be selectively hydrolyzed to provide the azido acid $\mathbf{1 4}$ in nearly quantitative yield.

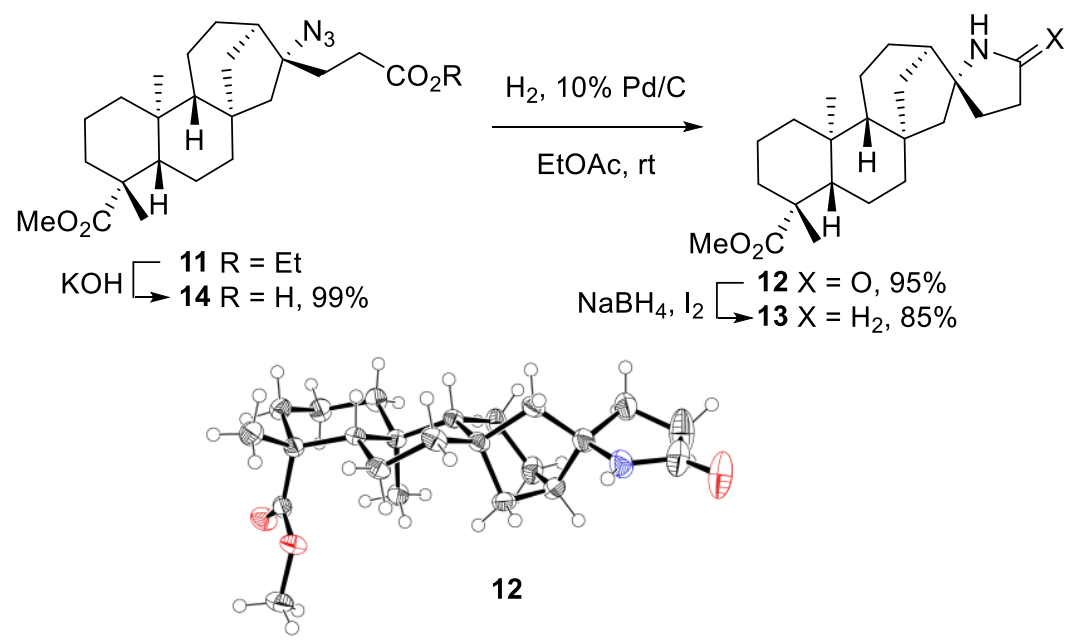

Scheme 4. Conversion of the azidoalkylated product 11 into lactam 12, pyrrolidine $\mathbf{1 3}$ and azido acid 14. X-ray crystal structure of lactam 12 (ellipsoids drawn at 50\% probability, CCDC 2023783).

We also observed that the nature of the iodide represents an important factor affecting azidoalkylation of acid $\mathbf{1}$ and ester $\mathbf{6}$. Our attempt to use iodoacetonitrile instead of ethyl iodoacetate did not result in any azidoalkylated product under $\mathrm{Et}_{3} \mathrm{~B}$ initiation. The major reaction products are the unsaturated nitriles 15-17 (Scheme 5), similar in structure to esters 7 and 8 . This result is presumably due to the formation of an unstable iodide intermediate in the case of the nitrile, while the ester radical adduct reacts directly with the sulfonyl azide without the formation of a transient iodide. Indeed, iodoacetonitrile is a better iodine atom donor than the corresponding ester by about two orders of magnitude [37]. Trace amounts of an azide obtained from the azidoalkylation of acid 1 have been tentatively identified based on the characteristic ${ }^{13} \mathrm{C}$ NMR peak at $72.25 \mathrm{ppm}$, corresponding to the $\mathrm{C}-\mathrm{N}_{3}$ carbon atom. The isolation of this minor product turned out to be impossible using standard chromatography techniques.

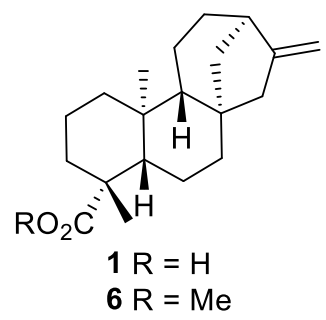<smiles>CC[R15](C)(C)NS(=O)(=O)O[Na]</smiles>

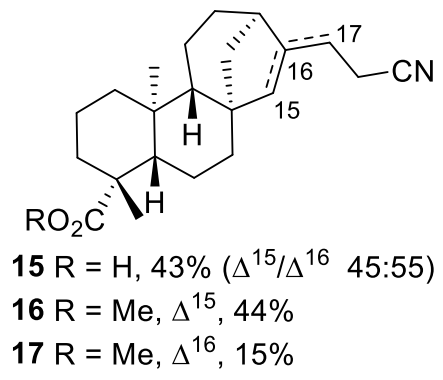

Scheme 5. Azidoalkylation attempt of methyl-ent-kaurenoate 6 with iodoacetonitrile. 


\subsection{Radical Addition to $15 \alpha$-Hydroxy-ent-Kaurenoates}

The modification of methyl $15 \alpha$-hydroxy-ent-kaurenoate 20 was investigated next. The hydroxylated ent-kauranic acid derivative $\mathbf{1 8}$ comes together with ent-kaurenoic acid $\mathbf{1}$ in the sunflower vegetal mass as an angelic acid ester 19. The latter can be easily isolated and hydrolyzed to provide pure $\mathbf{1 8}$ (Scheme 6). Methylation of $\mathbf{1 8}$ with diazomethane furnished quantitatively the methyl ester $\mathbf{2 0}$ used for the radical mediated modification experiments.

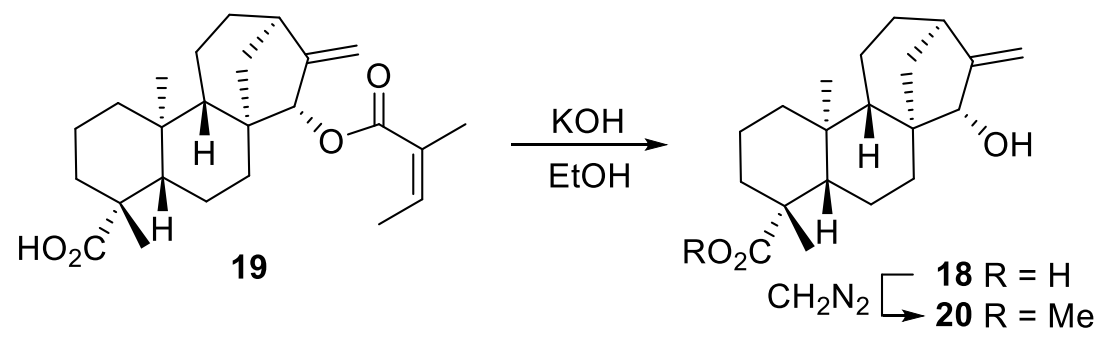

Scheme 6. Preparation of methyl 15 $\alpha$-hydroxy-ent-kaurenoate 20.

\subsubsection{Iodine ATRA Reactions}

Upon heating the ester $\mathbf{2 0}$ with ethyl iodoacetate in benzene under DLP initiation, a mixture of two major unsaturated compounds E-21 and 22 was obtained (Scheme 6). In line with similar ATRA experiments with substrates $\mathbf{1}$ and $\mathbf{6}$, the hypothetically formed tertiary iodide is unstable, and rapid HI elimination leads to the unsaturated products [18]. Due to the presence of the alcohol moiety in $\mathbf{2 0}$, lactonization of the Z-alkene resulting from the ATRA-elimination process occurred spontaneously under these reaction conditions leading to the unsaturated lactone 22. The $E$-alkene cannot cyclize and the ester $E$-21 is formed. Chromatographic separation of E-21 from lactone 22 proved to be difficult due to their similar retention factors. Acetylation of the mixture of $\mathbf{2 1}$ and $\mathbf{2 2}$ with acetic anhydride resulted in the formation of acetate $\mathbf{2 3}$ which could be easily separated by chromatography and provided satisfactory analytical data for full characterization (Scheme 7). The structure of lactone 22 was obtained by single crystal X-ray crystallography (Scheme 7) [36]. The basic challenge at this stage was the demonstration of the $E$-configuration of the exocyclic double bond in acetate 23 and indirectly in alcohol 21. The convincing proof came from the experiments on azidoalkylation of the allylic alcohol 20 (see below).

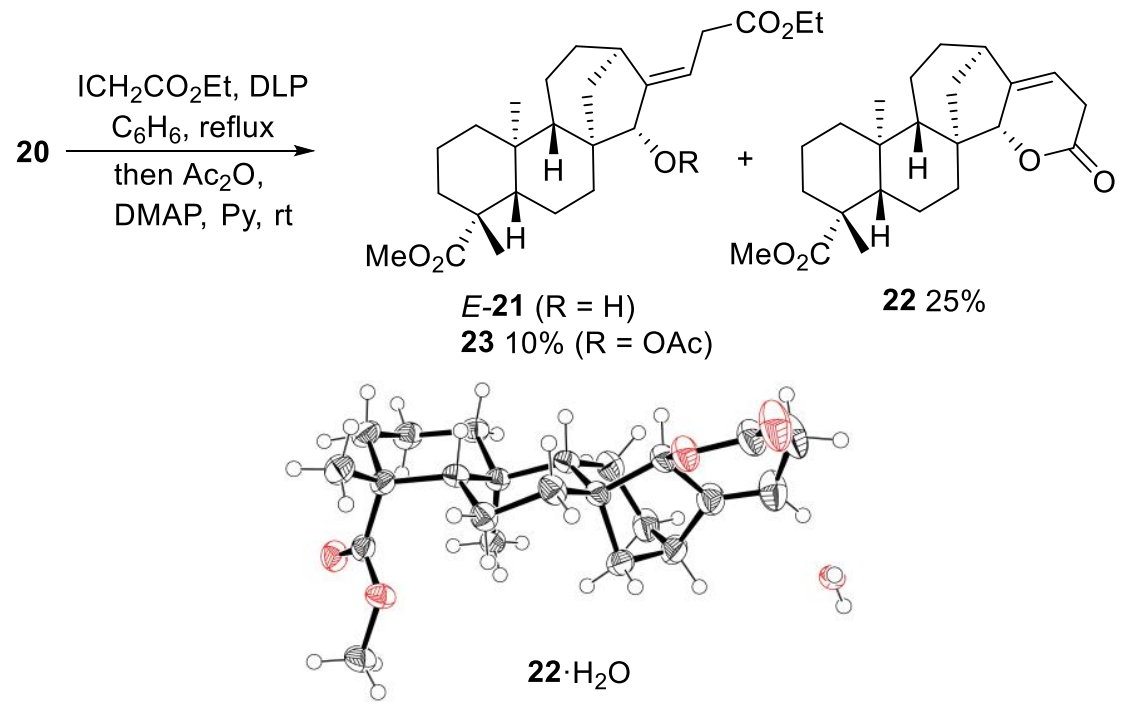

Scheme 7. Addition of ethyl iodoacetate to 20. X-ray crystal structure of lactone $22 \cdot \mathrm{H}_{2} \mathrm{O}$ (ellipsoids drawn at 50\% probability, CCDC 2023785). 


\subsubsection{Azidoalkylation}

The azidoalkylation process was investigated under similar conditions that brought about optimal conversion of methyl ent-kaurenoate $\mathbf{6}$ to the azide 11. Upon treatment of 20 with ethyl iodoacetate in the presence of hexabutylditin-DTBHN and phenylsulfonyl azide, an optimal $90 \%$ conversion of starting material was achieved after $5 \mathrm{~h}$ of heating at reflux in benzene (Scheme 8). However, no azide was detected but the already known ester E-21 and lactone $\mathbf{2 2}$ were obtained. When the same reaction was run at room temperature under triethylborane initiation, again no azide was formed, and a mixture of unsaturated esters $E$ 21 and Z-21 was obtained (Scheme 8). Interestingly, the lower reaction temperature impedes the lactonization of Z-21 and its isolation was possible. The absence of the azidoalkylated product is presumably a consequence of the increased steric hindrance and decreased nucleophilicity of the hydroxylated radical adduct relative to the non-hydroxylated one, leading to 11.

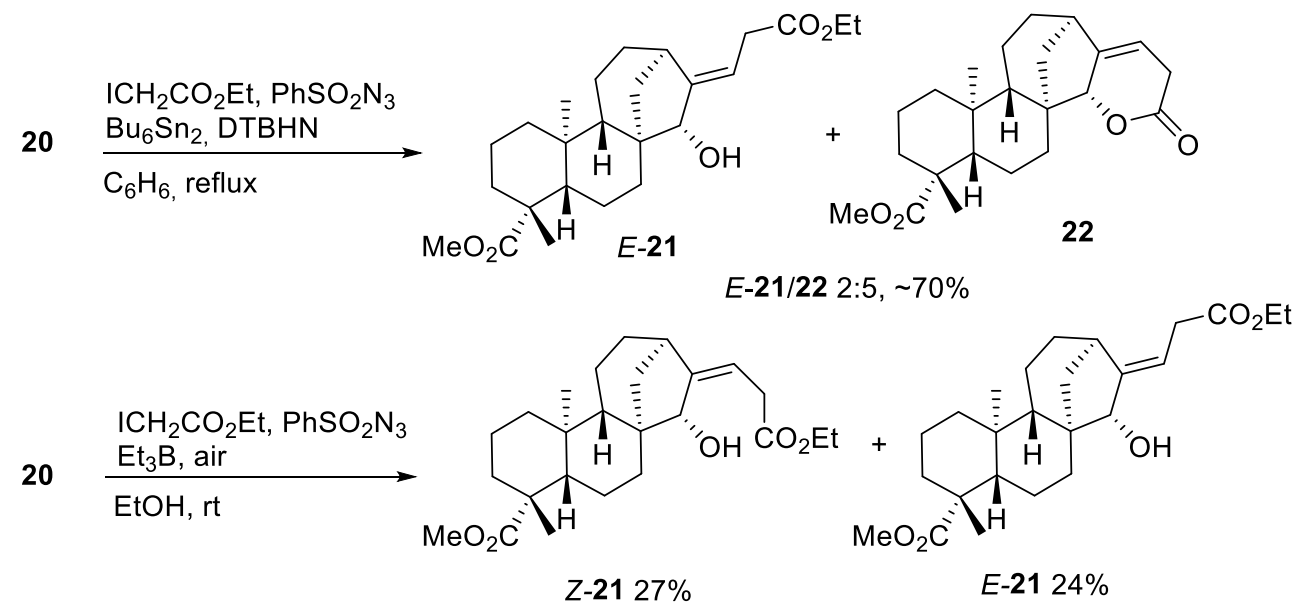

Scheme 8. Iodine-ATRA between methyl 15 $\alpha$-hydroxy-ent-kaurenoate 20 and ethyl iodoacetate.

Having accessed all four compounds E-21, Z-21, 22, and 23 of sufficient purity, we were able to draw conclusions on their stereochemistry based on the ${ }^{1} \mathrm{H}$ NMR spectra, in particular upon examining the splitting character of $C$ (18) methylenic protons adjacent to the carboxylic group in these compounds (Figure 3).
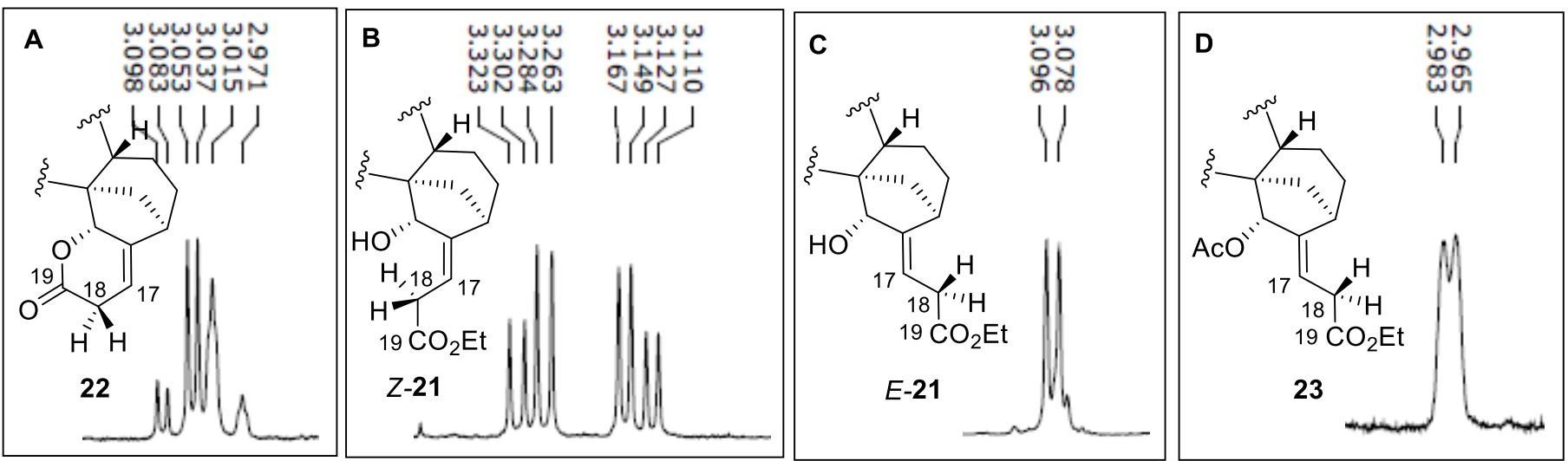

Figure 3. ${ }^{1} \mathrm{H}$ NMR spectra sections of lactone 21 (A), ester 24 (B), ester 22 (C), and acetate 23 (D).

First, these methylenic protons in 22 resonate at $3.02 \mathrm{ppm}$ (Figure $3 \mathrm{~A}$ ) and show a relevant geminal coupling, which is due to the rigid cyclic structure and strong influence of the adjacent oxygenated moieties. The vicinal coupling with the vinylic proton is in accordance with dihedral angles observed in X-ray pictures. The ${ }^{1} \mathrm{H}$ NMR spectrum of Z-21 shows a similar splitting profile of the methylenic group at C (18) (Figure 3B, 3.11-3.32 ppm) 
to that observed in lactone 22 , demonstrating the proximity of this group to the hydroxyl at $C$ (15) position, leading to a larger chemical shift difference between two geminal protons at $C$ (18). On the other hand, both C (18) methylenic protons in ester E-21 and acetate 23 are almost equivalent due to the conformational mobility of the lateral chain and impeded interaction with the oxygenated functional group. Their NMR peaks represent doublets, resonating at $3.08 \mathrm{ppm}$ (Figure 3C) and $2.97 \mathrm{ppm}$ (Figure 3D), respectively, and having an identical coupling constant of $7.3 \mathrm{~Hz}$ with vinylic protons from $\mathrm{C}$ (17).

Interestingly, an attempt to run the azidoalkylation process with iodoacetic acid instead of its ethyl ester led to the azide $\mathbf{2 4}$ and lactone 22 (Scheme 9). The azidoalkylation was also achieved with iodoacetonitrile as the radical precursor. Performing the reaction with triethylborane as radical initiator was compatible with the free carboxyl group in the starting ent-kaurane 18 and resulted in product 25, opening up more opportunities for further functionalization.

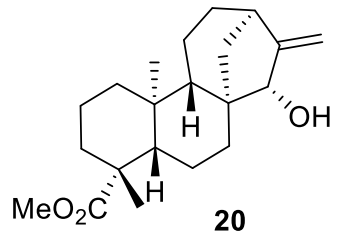

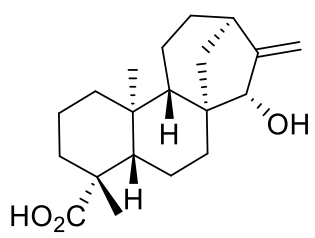

18
$\mathrm{ICH}_{2} \mathrm{CO}_{2} \mathrm{H}, \mathrm{PhSO}_{2} \mathrm{~N}_{3}$ $\underset{\mathrm{Bu}_{6} \mathrm{H}_{6}, \text { reflux }}{\longrightarrow}$

$\mathrm{ICH}_{2} \mathrm{CN}, \mathrm{PhSO}_{2} \mathrm{~N}_{3}$ $\mathrm{Et}_{3} \mathrm{~B}$, air $\mathrm{EtOH}, \mathrm{rt}$

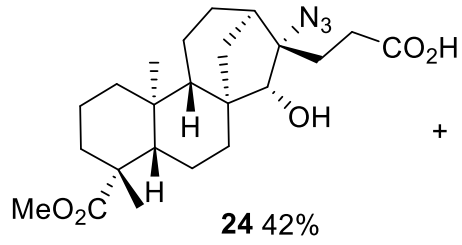

$+2228 \%$

Scheme 9. Azidoalkylation of methyl 15- $\alpha$-hydroxy-ent-kaurenoate 20 and 15- $\alpha$-hydroxy-entkaurenoic acid 18 with iodoacetic acid and iodoacetonitrile.

Further transformations of azido-acid 24 included its methylation with diazomethane to ester 26, which could be converted into lactam 27 during reduction of the azide under hydrogenation conditions (Scheme 10).
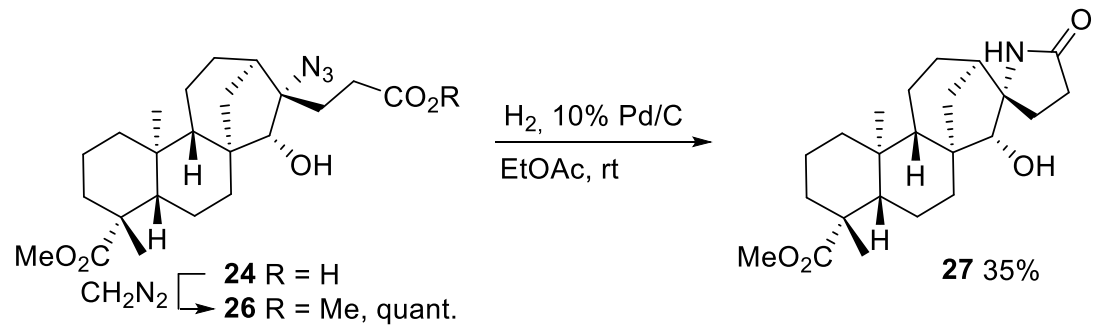

Scheme 10. Conversion of the azidoalkylated acid 24 into ester 26 and lactam 27.

\subsection{Cytotoxicity Testing}

The described processes resulted in a small library of new compounds with modified ent-kaurane skeletons, and their cytotoxic activity has been investigated. Proliferation assays have been performed in seven different tumor cell lines as shown in Table 1: Capan-1 (pancreatic adenocarcinoma), HCT-116 (colorectal carcinoma), NCI-H460 (lung carcinoma), DND-41 (acute lymphoblastic leukemia), HL-60 (acute myeloid leukemia), K-562 (chronic myeloid leukemia), and Z-138 (non-Hodgkin lymphoma). A parallel cytotoxicity assay was performed on non-cancerous retina cells (hTERT RPE-1) in order to estimate the selectivity of the investigated compounds towards tumor cells. The inhibition of cell proliferation was calculated as $\mathrm{IC}_{50}$ by interpolation based on the semi-log dose response. Docetaxel and staurosporine have been included as positive controls. The data in Table 1 show that a significant 
portion of the investigated compounds demonstrate relevant antitumoral activity. In particular, compounds 11-13, 22, 26, and $\mathbf{2 7}$ were active with $\mathrm{IC}_{50}$ values below $1 \mu \mathrm{M}$ concentrations. We were also pleased to observe a selective activity for some compounds, based on much higher $\mathrm{IC}_{50}$ for normal non-cancerous cells. The calculated selectivity indices (SI), i.e., the ratio of the $\mathrm{IC}_{50}$ for normal cells to the $\mathrm{IC}_{50}$ for the corresponding tumor cells [38], are higher than the threshold value of 3 for several samples (see table in the supplementary material for details). The highest selectivity indices were obtained for compounds 11, 12, 13, 26, and 27, with $I_{50}$ values for retina (hTERT RPE-1) cells up to 43-fold higher than those for cancerous cells. These data are indicative of a potential therapeutic index for these compounds, which can be explored in subsequent in vivo toxicity tests.

Table 1. Antiproliferative activity of ent-kauranic derivatives. DT-docetaxel; SP-staurosporine.

\begin{tabular}{|c|c|c|c|c|c|c|c|c|c|}
\hline \multirow[b]{2}{*}{ Compound } & \multirow[b]{2}{*}{ Conc. Unit } & \multicolumn{8}{|c|}{$\mathrm{IC}_{50}$} \\
\hline & & $\begin{array}{c}\text { hTERT } \\
\text { RPE-1 }\end{array}$ & Capan-1 & НCТ-116 & NCI-H460 & DND-41 & HL-60 & K-562 & Z-138 \\
\hline 7 & $\mu \mathrm{M}$ & $29.2 \pm 1.2$ & $37.1 \pm 3.9$ & $30.7 \pm 16.4$ & $12.0 \pm 1.5$ & $36.5 \pm 0.7$ & $19.6 \pm 7.7$ & $24.7 \pm 11.8$ & $27.6 \pm 15.5$ \\
\hline 11 & $\mu \mathrm{M}$ & $1.8 \pm 0.4$ & $1.7 \pm 0.5$ & $1.0 \pm 0.4$ & $1.3 \pm 0.1$ & $1.4 \pm 0.3$ & $3.0 \pm 1.4$ & $8.8 \pm 2.2$ & $0.5 \pm 0.2$ \\
\hline 12 & $\mu \mathrm{M}$ & $7.6 \pm 0.5$ & $1.2 \pm 0.7$ & $0.8 \pm 0.2$ & $1.4 \pm 0.1$ & $21.4 \pm 10.1$ & $38.3 \pm 17.8$ & $36.4 \pm 11.5$ & $52.0 \pm 33.4$ \\
\hline 13 & $\mu \mathrm{M}$ & $32.2 \pm 2.0$ & $11.5 \pm 1.0$ & $11.6 \pm 0.5$ & $1.0 \pm 0.1$ & $6.1 \pm 1.1$ & $8.3 \pm 1.3$ & $3.2 \pm 1.0$ & $9.5 \pm 0.9$ \\
\hline 14 & $\mu \mathrm{M}$ & $26.2 \pm 0.9$ & $44.5 \pm 8.3$ & $5.8 \pm 0.1$ & $31.1 \pm 1.6$ & $44.5 \pm 4.8$ & $46.2 \pm 9.1$ & 41.0 & 22.7 \\
\hline 16 & $\mu \mathrm{M}$ & $38.2 \pm 5.1$ & $18.1 \pm 3.4$ & $19.0 \pm 5.7$ & $15.4 \pm 6.0$ & $7.8 \pm 1.0$ & $33.6 \pm 2.6$ & $58.4 \pm 2.5$ & $22.1 \pm 11.4$ \\
\hline 22 & $\mu \mathrm{M}$ & $1.4 \pm 0.1$ & $1.3 \pm 0.6$ & $0.5 \pm 0.2$ & $1.4 \pm 0.3$ & $2.3 \pm 0.3$ & $3.7 \pm 1.3$ & $2.5 \pm 0.1$ & $2.4 \pm 1.1$ \\
\hline 24 & $\mu \mathrm{M}$ & $31.7 \pm 3.1$ & $33.2 \pm 7.6$ & $18.8 \pm 8.0$ & $41.8 \pm 5.3$ & $38.9 \pm 4.1$ & $49.3 \pm 5.0$ & $76.3 \pm 1.4$ & $25.2 \pm 0.3$ \\
\hline 25 & $\mu \mathrm{M}$ & $33.6 \pm 4.5$ & $6.4 \pm 1.5$ & $34.4 \pm 0.5$ & $34.0 \pm 2.9$ & $36.4 \pm 9.8$ & $>100$ & $>100$ & $52.0 \pm 17.4$ \\
\hline 26 & $\mu \mathrm{M}$ & $25.9 \pm 0.3$ & $8.3 \pm 1.1$ & $9.9 \pm 2.7$ & $0.6 \pm 0.2$ & $6.6 \pm 1.3$ & $41.1 \pm 15.9$ & $36.9 \pm 0.2$ & $21.6 \pm 5.4$ \\
\hline 27 & $\mu \mathrm{M}$ & $27.7 \pm 4.3$ & $3.7 \pm 1.7$ & $4.0 \pm 3.7$ & $1.9 \pm 0.2$ & $8.3 \pm 2.0$ & $38.0 \pm 11.8$ & $56.5 \pm 2.8$ & $39.8 \pm 10.9$ \\
\hline DT & $\mathrm{nM}$ & $18.7 \pm 4.8$ & $4.2 \pm 1.8$ & $2.2 \pm 0.8$ & $5.5 \pm 1.3$ & $4.7 \pm 1.2$ & $4.3 \pm 1.6$ & $5.2 \pm 1.2$ & $3.7 \pm 0.7$ \\
\hline SP & $\mathrm{nM}$ & 1.0 & $6.2 \pm 1.8$ & 1.5 & $2.2 \pm 0.8$ & $8.6 \pm 1.5$ & $9.1 \pm 1.6$ & $27.9 \pm 3.2$ & $6.7 \pm 4.4$ \\
\hline
\end{tabular}

From a structural topology point of view, the most active compounds show some relevant similarities (Figure 4). First of all, most of the active compounds include nitrogen containing functional groups. The second structural convergence relates to the cyclic backbone, which includes an extra cycle to the natural ent-kauranic framework. Exceptions are azides $\mathbf{1 1}$ and 26. Finally, three of the four most relevant cytotoxic compounds with high selectivity towards tumor cells are heterocycles 12, 13, and 27 with a spirocyclic fragment. To the best of our knowledge, such derivatives of ent-kauranic compounds have never been reported in SAR studies. The activity levels of these compounds is much higher than that of the reference drug Cisplatin ( IC $_{50} 16.5$ for HCT-116 and 5.33 for NCI-H460) and in the same range as the currently marketed drug midostaurine, with $\mathrm{IC}_{50} 0.237$ for HCT-116 and 0.43 for NCI-H460 [39]. In fact, compounds 12 and 27 share the same $\gamma$-lactam unit with both natural staurosporine and synthetic midostaurine. Although this pharmacophore is becoming increasingly more studied [40], little is known about the properties of $\gamma$-spiro-1lactams, which are extremely rare in the literature. The same relates to their mechanism of interaction with cellular targets [41]. Following in vivo toxicity studies can reveal the therapeutic potential of the reported new ent-kauranic derivatives. 

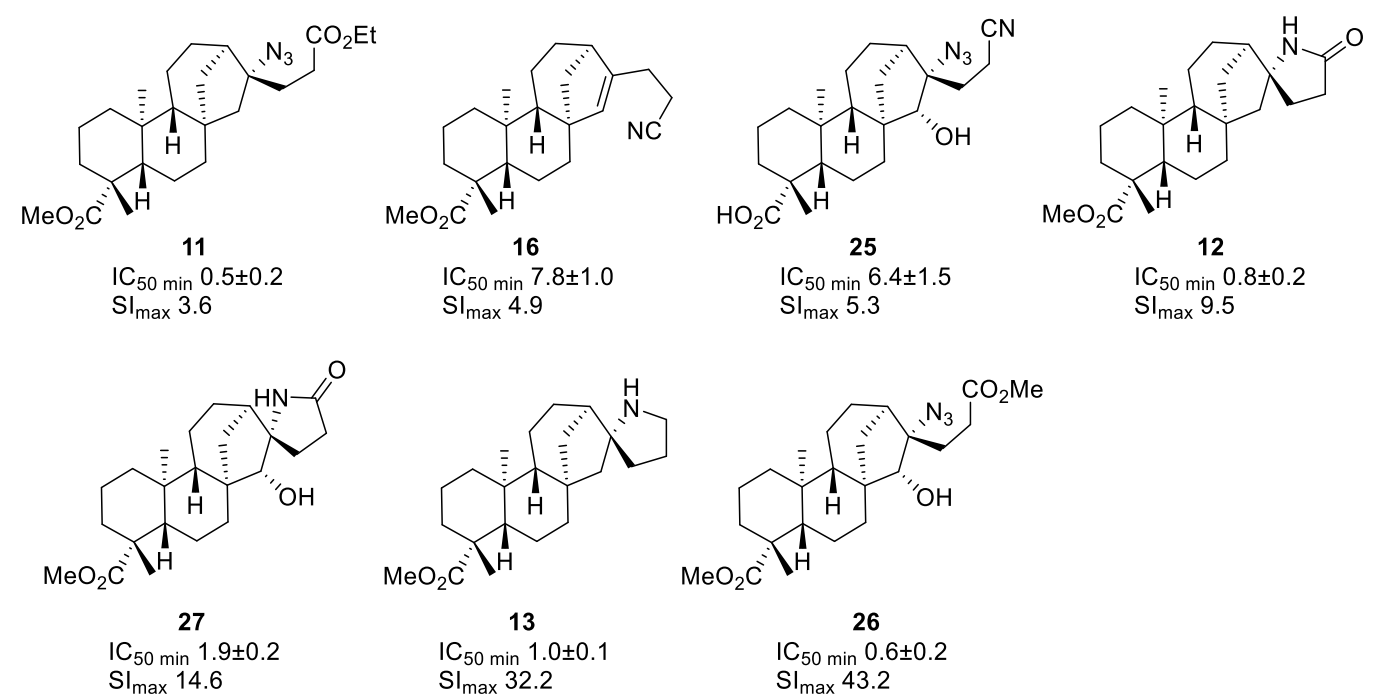

Figure 4. Relevant cytotoxic activity parameters for selected compounds.

\section{Materials and Methods}

\subsection{Chemistry General Section}

IR spectra were recorded on a Perkin-Elmer (Beaconsfield, UK) Spectrum 100 FTIR spectrophotometer using the universal ATR sampling accessory. NMR spectra were recorded in $\mathrm{CDCl}_{3}$ on a Bruker (Rheinstetten, Germany) Avance III spectrometer (400.13 and $100.61 \mathrm{MHz}$ ). Chemical shifts $(\delta)$ are reported in parts per million (ppm) downfield from tetramethylsilane $\mathrm{Si}\left(\mathrm{CH}_{3}\right)_{4}\left(\delta=0.00\right.$ for ${ }^{1} \mathrm{H}$ NMR spectra) using residual solvent signal as an internal standard: $\delta$ singlet $7.26\left({ }^{1} \mathrm{H}\right)$, triplet $77.0\left({ }^{13} \mathrm{C}\right)$ for $\mathrm{CDCl}_{3}$ or $\delta$ singlet $4.87\left({ }^{1} \mathrm{H}\right)$, septet $49.0\left({ }^{13} \mathrm{C}\right)$ for $\mathrm{CD}_{3} \mathrm{OD}$. Multiplicities are given as $\mathrm{s}$ (singlet), $\mathrm{d}$ (doublet), $\mathrm{t}$ (triplet), $\mathrm{q}$ (quadruplet), $\mathrm{m}$ (multiplet), and bs (broad signal). Coupling constant $(J)$ is reported in $\mathrm{Hz}$. In case of mix of products, selected values for ${ }^{1} \mathrm{H}$ NMR were reported (as specified in the description). In ${ }^{13} \mathrm{C}$ NMR spectra, the peak positions are reported to one decimal unless the difference in chemical shift between two signals (for example for regio-/diastereoisomers) is small and required two decimals. Optical rotations were measured in $\mathrm{CHCl}_{3}$ or $\mathrm{MeOH}$ on a Jasco DIP 370 polarimeter, using a 5-cm cell. GC-MS experiments were performed on an Agilent 7890A (Wilmington, DE, USA) chromatograph equipped with a quadrupole MS detector MSD 5975C and an HP-5ms capillary column $(30 \mathrm{~m} / 0.25 \mathrm{~mm} / 0.25 \mu \mathrm{m})$. Analytical TLC was performed on Fluka Silica Alu foils. Usual workup included dilution with brine and extraction with $\mathrm{Et}_{2} \mathrm{O}$. The organic phases have been dried over $\mathrm{Na}_{2} \mathrm{SO}_{4}$, filtered and the solvent evaporated under reduced pressure to provide the crude reaction product. Column chromatography (CC) was performed with Fluka Kieselgel 60 silica gel. All solvents were of reagent grade and other reagents have been used as received from suppliers. DLP was added in aliquot portions every $2 \mathrm{~h}$ to the solution of the corresponding olefin and iodide. Addition of $\mathrm{Et}_{3} \mathrm{~B}$ solutions (commercial) to the reaction mixtures was performed via a syringe with the needle immersed into the reaction mixture to avoid direct contact of $\mathrm{Et}_{3} \mathrm{~B}$ drops with air. ATRA reactions have been performed with ethyl iodoacetate unless otherwise specified. Benzene and THF have been dried according to standard procedures and distilled before use.

\subsection{Crystal-Structure Determination}

The crystals were mounted in air at ambient conditions. All measurements were made on an Oxford Diffraction SuperNova area-detector diffractometer [42] using mirror optics monochromated Mo $K \alpha$ radiation $(\lambda=0.71073 \AA)$ and Al filtered [43]. Data reduction was performed using the CrysAlisPro [42] program. The intensities were corrected for Lorentz and polarization effects, and an absorption correction based on the multi-scan method using SCALE3 ABSPACK in CrysAlisPro [42] was applied. Data collection, refinement 
parameters and other specific experimental details are given in the Supplementary Materials. The structure was solved by direct methods using SHELXT [44], which revealed the positions of all non-hydrogen atoms of the title compound. The non-hydrogen atoms were refined anisotropically. All $\mathrm{H}$-atoms were placed in geometrically calculated positions and refined using a riding model where each $\mathrm{H}$-atom was assigned a fixed isotropic displacement parameter with a value equal to $1.2 \mathrm{Ueq}$ of its parent atom. Refinement of the structure was carried out on $F^{2}$ using full-matrix least-squares procedures, which minimized the function $\Sigma \mathrm{w}\left(\mathrm{F}_{\mathrm{o}}{ }^{2}-\mathrm{F}_{\mathrm{c}}{ }^{2}\right)^{2}$. The weighting scheme was based on counting statistics and included a factor to downweight the intense reflections. All calculations were performed using the SHELXL-2014/7 [45] program in OLEX2 [46].

\subsection{Cytotoxicity Testing}

\subsubsection{Cell Culture and Reference Compounds}

All cell lines (HL-60, K-562, Z-138, Capan-1, HCT-116, NCI-H460 and hTERT RPE-1) were acquired from the American Type Culture Collection (ATCC, Manassas, VA, USA), except for the DND-41 cell line, which was purchased from the Deutsche Sammlung von Mikroorganismen und Zellkulturen (DSMZ Leibniz-Institut, Braunschweig, Germany). All cell lines were cultured as recommended by the suppliers. Culture media were purchased from Gibco Life Technologies, USA, and supplemented with 10\% fetal bovine serum (HyClone, GE Healthcare Life Sciences, Logan, UT, USA). Reference inhibitor compounds staurosporine and docetaxel were obtained from Selleckchem (Munich, Germany). All stock solutions were prepared in DMSO.

\subsubsection{Cell Proliferation Assays}

Adherent cell lines Capan-1, HCT-116 and NCI-H460 cells were seeded at a density between 500 and 1500 cells per well in 384-well clear-bottomed tissue culture plates (Greiner). After overnight incubation, cells were treated with the test compounds at seven different concentrations ranging from 100 to $6.4 \times 10^{-3} \mu \mathrm{M}$. Suspension cell lines DND-41, HL-60, K-562, and Z-138 were seeded at densities ranging from 2500 to 5500 cells per well in 384-well clear-bottomed tissue culture plates containing the test compounds at the same seven concentration points. The plates were incubated at $37^{\circ} \mathrm{C}$ and monitored for $72 \mathrm{~h}$ in an IncuCyte ${ }^{\circledR}$ device (Essen BioScience Inc., Ann Arbor, MI, USA) for real-time imaging. Images were taken every $3 \mathrm{~h}$, with one field imaged per well under $10 \times$ magnification. Cell growth was then quantified based on the percent cellular confluence as analysed by the IncuCyte ${ }^{\circledR}$ image analysis software and used to calculate $\mathrm{IC}_{50}$ values by linear interpolation. All tests have been performed in duplicate and the average values have been calculated. The corresponding mean values and deviations are provided in Table 1.

\subsection{Experimental Section \\ DLP-mediated ATRA to methyl ent-kaurenoate}

Methyl ent-kaurenoate 6 (50 mg, $0.16 \mathrm{mmol})$ in dry $\mathrm{C}_{6} \mathrm{H}_{6}(5 \mathrm{~mL})$ was treated with ethyl iodoacetate $(28 \mu \mathrm{L}, 0.24 \mathrm{mmol})$ and DLP $(3 \mathrm{mg}, 0.008 \mathrm{mmol})$. The reaction mixture was heated on reflux under $\mathrm{N}_{2}$ for $24 \mathrm{~h}$. The mixture was purified by CC (hexane/EtOAc 98:2) and gave unchanged starting material $(40 \mathrm{mg}, 80 \%)$ and a mixture of compounds 7,8 and 9 (10 mg, 15\%).

\section{Ester 7}

Pale yellow viscous oil. $[\alpha]_{\mathrm{D}}^{20}=-45.8\left(\mathrm{c}=8.13, \mathrm{CHCl}_{3}\right) . \mathrm{IR}\left(\nu, \mathrm{cm}^{-1}\right): 3804,3736,3674$, 3608, 2927, 1728, 1445, 1231, 1156. ${ }^{1} \mathrm{H}$ NMR $\left(400 \mathrm{MHz}, \mathrm{CDCl}_{3}\right) \delta_{\mathrm{H}}: 5.07(\mathrm{~s}, 1 \mathrm{H}, \mathrm{CH}-15), 4.13$ $\left(\mathrm{q}, J=7.1 \mathrm{~Hz}, 2 \mathrm{H},-\mathrm{CO}_{2} \mathrm{CH}_{2} \mathrm{CH}_{3}\right), 3.63\left(\mathrm{~s}, 3 \mathrm{H},-\mathrm{CO}_{2} \mathrm{CH}_{3}\right), 2.44-2.49\left(\mathrm{~m}, 2 \mathrm{H},-\mathrm{CH}_{2}-\mathrm{COOEt}\right)$, $1.25\left(\mathrm{t}, J=7.1 \mathrm{~Hz}, 3 \mathrm{H},-\overline{\mathrm{CO}}_{2} \mathrm{CH}_{2} \mathrm{CH}_{3}\right), 1.16\left(\mathrm{~s}, 3 \mathrm{H}, \mathrm{CH}_{3}-20\right), 0.83\left(\mathrm{~s}, 3 \mathrm{H}, \mathrm{CH}_{3}-22\right), 2.38-0.93$ $(\mathrm{m}, 21 \mathrm{H}) .{ }^{13} \mathrm{C}$ NMR $\left(100 \mathrm{MHz}, \overline{\mathrm{CDCl}}_{3}\right) \delta_{\mathrm{C}}: 178.0,173.4,145.1,134.4,60.2,56.9,51.0,49.0$, $47.8,43.9,43.8,40.8,39.6,39.5,38.2,32.4,29.7,28.7,25.4,25.3,20.8,19.2,18.9,15.2,14.2$. GCMS $m / z$ calculated for $\left[\mathrm{C}_{25} \mathrm{H}_{38} \mathrm{O}_{4}\right]^{+}: 402.28$; found: 402.3 . 
Ester 8

Mixture of 2 diastereomers. IR (v, cm $\left.{ }^{-1}\right)$ : 3674, 2931, 1728, 1449, 1234, 1171, 1150. ${ }^{1} \mathrm{H}$ NMR $\left(400 \mathrm{MHz}, \mathrm{CDCl}_{3}\right)$ selected values, $\delta_{\mathrm{H}}: 4.15-4.09\left(\mathrm{~m}, 2 \mathrm{H},-\mathrm{CO}_{2} \mathrm{CH}_{2} \mathrm{CH}_{3}\right), 3.64(\mathrm{~s}$, $\left.3 \mathrm{H},-\mathrm{CO}_{2} \mathrm{CH}_{3}\right), 1.25\left(\mathrm{~m}, 3 \mathrm{H},-\mathrm{CO}_{2} \mathrm{CH}_{2} \mathrm{CH}_{3}\right), 1.17\left(\mathrm{~m}, 3 \mathrm{H}, \mathrm{CH}_{3}-20\right), 0.82\left(\mathrm{~m}, 3 \mathrm{H}, \mathrm{CH}_{3}-\right.$ 22). ${ }^{13} \mathrm{C}$ NMR $\left(100 \mathrm{MHz}, \mathrm{CDCl}_{3}\right)$ selected values, $\delta_{\mathrm{C}}: 178.04 / 178.03,172.57 / 172.41$, 149.98/148.94, 110.39/109.94, 60.36, 57.12/57.07, 55.17/55.10, 51.03, 49.32/46.21, 43.84, $43.59 / 43.48,41.41 / 41.19,40.80,39.63 / 39.47,39.41 / 39.27,38.12,34.90 / 34.68,33.06 / 30.83$, $28.73,21.96,19.16,18.76 / 18.45,15.45 / 15.41,14.21 / 14.18$. GCMS $m / z$ calculated for $\mathrm{C}_{25} \mathrm{H}_{38} \mathrm{O}_{4}$ : 402.28; found: 402.3 .

Ester 9

Colorless oil. IR $\left(v, \mathrm{~cm}^{-1}\right)$ : 3750, 2921, 1729, 1506, 1448, 1370, 1191, 1042. ${ }^{1} \mathrm{H}$ NMR $\left(400 \mathrm{MHz}, \mathrm{CDCl}_{3}\right) \delta_{\mathrm{H}}: 4.12\left(\mathrm{q}, J=7.9 \mathrm{~Hz}, 2 \mathrm{H},-\mathrm{CO}_{2} \mathrm{CH}_{2} \mathrm{CH}_{3}\right), 3.63\left(\mathrm{~s}, 3 \mathrm{H},-\mathrm{CO}_{2} \mathrm{CH}_{3}\right)$, 2.86-2.60 (m, 1H), $2.29\left(\mathrm{~m}, 2 \mathrm{H}, \mathrm{CH}_{2}-17\right), 1.25\left(\mathrm{t}, J=7.1 \overline{\mathrm{Hz}}, 3 \mathrm{H},-\mathrm{CO}_{2} \mathrm{CH}_{2} \mathrm{CH}_{3}\right), 1.16(\mathrm{~s}, 3 \mathrm{H}$, $\left.\mathrm{CH}_{3}-20\right), 0.81$ (s, 3H, $\left.\mathrm{CH}_{3}-22\right), 2.18-0.79(\mathrm{~m}, 23 \mathrm{H}) .{ }^{13} \mathrm{C} \mathrm{NMR}\left(100 \mathrm{MHz}, \mathrm{CDCl}_{3}\right) \delta_{\mathrm{C}}: 178.10$, $174.03,60.17,57.15,56.61,51.05,46.74,44.41,43.89,42.22,40.87,40.51,40.13,39.48,38.49$, $38.21,34.09,28.77,26.66,25.88,22.24,19.19,19.14,15.42,14.28$. GCMS $m / z$ calculated for $\mathrm{C}_{25} \mathrm{H}_{40} \mathrm{O}_{4}$ : 404.29; found: 404.3 .

$\mathrm{Bu}_{6} \mathrm{Sn}_{2}$-mediated ATRA to methyl ent-kaurenoate

Methyl ent-kaurenoate $6(50 \mathrm{mg}, 0.158 \mathrm{mmol})$ in dry $\mathrm{C}_{6} \mathrm{H}_{6}(3 \mathrm{~mL})$ was treated under $\mathrm{N}_{2}$ with ethyl iodoacetate $(37.4 \mu \mathrm{L}, 0.316 \mathrm{mmol}), \mathrm{Bu}_{6} \mathrm{Sn}_{2}(120 \mu \mathrm{L}, 0.237 \mathrm{mmol})$, and DTBHN $(0.8 \mathrm{mg}, 0.005 \mathrm{mmol})$. The reaction mixture was refluxed for $2 \mathrm{~h}$. The crude product was purified by CC (hexane/EtOAc 98:2) and gave a 2:1:1 mixture of compounds 7, 8 , and 9 (61 mg, 88\% total yield). Separation of this mixture on a silver nitrate impregnated silica afforded a pure sample of ester 7 (45\% yield), along with esters 8 and 9 (22\% and $21 \%$ yield, respectively).

$\mathrm{Bu}_{6} \mathrm{Sn}_{2}$-mediated ATRA to ent-kaurenoic acid

ent-Kaurenoic acid 1 ( $87 \mathrm{mg}, 0.29 \mathrm{mmol})$ in dry benzene $(2 \mathrm{~mL})$ was treated under $\mathrm{N}_{2}$ with ethyl iodoacetate ( $\left.51.5 \mu \mathrm{L}, 0.44 \mathrm{mmol}\right), \mathrm{PhSO}_{2} \mathrm{~N}_{3}(159 \mathrm{mg}, 0.87 \mathrm{mmol}), \mathrm{Bu}_{6} \mathrm{Sn}_{2}$ $(222 \mu \mathrm{L}, 0.44 \mathrm{mmol})$, and DTBHN $(1.5 \mathrm{mg}, 0.087 \mathrm{mmol})$. The reaction mixture was refluxed for $2 \mathrm{~h}$ and after this time the crude product was purified by CC (pentane/EtOAc 90:10) giving compound 10, slightly contaminated with tin compounds (NMR). This impurified product was methylated with an ethereal solution of diazomethane and purified by CC (hexane/EtOAc 98:2) to afford azide $\mathbf{1 1}(90 \mathrm{mg}, 70 \%)$ as a colorless oil.

Azide 11

Colorless viscous oil. $[\alpha]_{\mathrm{D}}^{20}=-79.5\left(\mathrm{c}=0.84, \mathrm{CHCl}_{3}\right)$. IR $\left(\nu, \mathrm{cm}^{-1}\right): 2944,2873,2096$, 1727, 1502. ${ }^{1} \mathrm{H}$ NMR $\left(400 \mathrm{MHz}, \mathrm{CDCl}_{3}\right) \delta_{\mathrm{H}}: 4.12\left(\mathrm{q}, J=7.2 \mathrm{~Hz}, 2 \mathrm{H},-\mathrm{CO}_{2} \mathrm{CH}_{2} \mathrm{CH}_{3}\right), 3.62(\mathrm{~s}$, $\left.3 \mathrm{H},-\mathrm{CO}_{2} \mathrm{CH}_{3}\right), 2.42\left(\mathrm{t}, J=7.9 \mathrm{~Hz}, 2 \mathrm{H},-\mathrm{CH}_{2}-\mathrm{COOEt}\right), 1.25\left(\mathrm{t}, J=7.2 \mathrm{~Hz}, 3 \mathrm{H},-\mathrm{CO}_{2} \mathrm{CH}_{2} \mathrm{CH}_{3}\right)$, $1.14\left(\mathrm{~s}, 3 \mathrm{H}, \mathrm{CH}_{3}-20\right), 0.80\left(\mathrm{~s}, 3 \mathrm{H}, \mathrm{CH}_{3}-22\right), 2.06-0.75(\mathrm{~m}, 23 \mathrm{H}) .{ }^{13} \mathrm{C} \mathrm{NMR}\left(100 \mathrm{MHz}, \mathrm{CDCl}_{3}\right)$ $\delta_{C}: 177.9,173.4,73.1,60.5,56.7,55.8,51.5,51.1,44.7,44.3,43.7,41.4,40.6,39.4,38.0,37.7$, $30.3,29.7,28.7,26.1,22.0,19.0,18.5,15.3,14.2$. GCMS $m / z$ calculated for $\left[\mathrm{C}_{25} \mathrm{H}_{39} \mathrm{~N}_{3} \mathrm{O}_{4}\right]$ : 445.28; found: $402.3\left(\mathrm{M}-\mathrm{HN}_{3}\right)$.

$\mathrm{Bu}_{6} \mathrm{Sn}_{2}$-mediated ATRA to methyl ent-kaurenoate

Methyl ent-kaurenoate $6(100 \mathrm{mg}, 0.36 \mathrm{mmol})$ in dry benzene $(2 \mathrm{~mL})$ was treated under $\mathrm{N}_{2}$ with ethyl iodoacetate $(64 \mu \mathrm{L}, 0.54 \mathrm{mmol}), \mathrm{PhSO}_{2} \mathrm{~N}_{3}(200 \mathrm{mg}, 1.08 \mathrm{mmol}), \mathrm{Bu}_{6} \mathrm{Sn}_{2}$ $(272 \mu \mathrm{L}, 0.54 \mathrm{mmol})$, and DTBHN ( $2 \mathrm{mg}, 0.01 \mathrm{mmol})$. The reaction mixture was refluxed for $2 \mathrm{~h}$. The crude product was purified by column chromatography (hexane/EtOAc 98:2) and gave the azide $\mathbf{1 1}$ (133 mg, 83\%).

$\mathrm{Et}_{3} \mathrm{~B}$-mediated ATRA to ent-kaurenoic acid 
ent-Kaurenoic acid 1 (44 mg, $0.146 \mathrm{mmol})$ in dry EtOH $(2 \mathrm{~mL})$ was treated under $\mathrm{N}_{2}$ with ethyl iodoacetate $(35 \mu \mathrm{L}, 0.292 \mathrm{mmol}), \mathrm{PhSO}_{2} \mathrm{~N}_{3}(80 \mathrm{mg}, 0.438 \mathrm{mmol}), \mathrm{Et}{ }_{3} \mathrm{~B}(0.6 \mathrm{~mL}$, $0.584 \mathrm{mmol})$. The reaction was stirred at room temperature overnight then diluted with brine and worked up. The crude product was purified by CC (hexane/EtOAc 94:6) giving pure compound 10 (39 mg, 60\%).

Azide 10

Pale yellow viscous oil. $[\alpha]_{\mathrm{D}}^{20}=-69.2\left(\mathrm{c}=1.9, \mathrm{CHCl}_{3}\right) . \mathrm{IR}\left(\nu, \mathrm{cm}^{-1}\right): 2935,2900,2872$, 2848, 2626, 2098, 1734, 1693. ${ }^{1} \mathrm{H} \mathrm{NMR}\left(400 \mathrm{MHz}, \mathrm{CDCl}_{3}\right) \delta(\mathrm{ppm}) 4.14(\mathrm{q}, J=7.1 \mathrm{~Hz}, 2 \mathrm{H}$, $\left.-\mathrm{CO}_{2} \mathrm{CH}_{2} \mathrm{CH}_{3}\right), 2.43\left(\mathrm{t}, J=8.1 \mathrm{~Hz}, 2 \mathrm{H},-\mathrm{CH}_{2}-\mathrm{COOEt}\right), 1.26\left(\mathrm{t}, \mathrm{J}=7.1 \mathrm{~Hz}, 3 \mathrm{H},-\mathrm{CO}_{2} \mathrm{CH}_{2} \mathrm{CH}_{3}\right)$, 1.22 (s, 3H, $\left.\mathrm{CH}_{3}-20\right), 0.93\left(\mathrm{~s}, 3 \mathrm{H}, \mathrm{CH}_{3}-22\right), 2.15-0.73(\mathrm{~m}, 23 \mathrm{H}) .{ }^{13} \mathrm{C} \mathrm{NMR}\left(100 \mathrm{MHz}, \mathrm{CDCl}_{3}\right)$ $\delta(\mathrm{ppm}) 184.9,173.4,73.1,60.6,56.7,55.8,51.5,44.7,44.3,43.7,41.4,40.5,39.6,37.7,37.6$, $30.3,29.7,28.9,26.1,21.8,18.9,18.5,15.4,14.2$.

$\mathrm{Et}_{3} \mathrm{~B}$-mediated ATRA to methyl ent-kaurenoate

Methyl ent-kaurenoate $6(50 \mathrm{mg}, 0.16 \mathrm{mmol})$ in dry EtOH $(2 \mathrm{~mL})$ was treated under $\mathrm{N}_{2}$ with ethyl iodoacetate $(39 \mu \mathrm{L}, 0.33 \mathrm{mmol}), \mathrm{PhSO}_{2} \mathrm{~N}_{3}(87 \mathrm{mg}, 0.47 \mathrm{mmol})$ and $\mathrm{Et}_{3} \mathrm{~B}$ $(0.47 \mathrm{~mL})$. The reaction mixture was stirred for $2 \mathrm{~h}$ at room temperature. The crude product was purified by column chromatography (pentane/EtOAc 98:2) and gave the azide 11 (43 $\mathrm{mg}, 60 \%)$.

\section{Lactam 12}

A solution of azide 11 (53 mg, $0.12 \mathrm{mmol})$ and 10\% Pd/C (10\% w/w) in dry EtOAc $(2 \mathrm{~mL})$ was stirred for $48 \mathrm{~h}$ at room temperature under $\mathrm{H}_{2}(1 \mathrm{~atm})$. The catalyst was filtered off, the solvent was removed under reduced pressure, and the crude purified by column chromatography $\left(\mathrm{CH}_{2} \mathrm{Cl}_{2} / \mathrm{MeOH}\right.$ 90:10) giving lactam 12 (42 mg, 95\%) as a white powder.

White powder. M.p. $150-152{ }^{\circ} \mathrm{C}$, from $\mathrm{CH}_{2} \mathrm{Cl}_{2} . \quad[\alpha]_{\mathrm{D}}^{20}=-77.4\left(\mathrm{c}=4.50, \mathrm{CHCl}_{3}\right)$. $\operatorname{IR}\left(v, \mathrm{~cm}^{-1}\right): 3676,3209,2937,2298,1712,1683 .{ }^{1} \mathrm{H}$ NMR $\left(400 \mathrm{MHz}, \mathrm{CDCl}_{3}\right) \delta_{\mathrm{H}}: 6.68(\mathrm{~s}, 1 \mathrm{H}$, -NH), 3.63 (s, 3H, $\left.-\mathrm{CO}_{2} \mathrm{CH}_{3}\right), 2.30\left(\mathrm{~m}, 2 \mathrm{H}, \mathrm{CH}_{2}-17\right), 2.05$ (d, J = 11.9 Hz, 2H, CH -18$), 1.15$ $\left(\mathrm{s}, 3 \mathrm{H}, \mathrm{CH}_{3}-20\right), 0.81\left(\mathrm{~s}, 3 \mathrm{H}, \mathrm{CH}_{3}-22\right), 2.36-0.79(\mathrm{~m}, 21 \mathrm{H}) .{ }^{13} \mathrm{C} \mathrm{NMR}\left(100 \mathrm{MHz}, \mathrm{CDCl}_{3}\right) \delta_{\mathrm{C}}$ : $177.9,176.8,67.2,57.6,56.9,55.6,51.1,46.6,44.9,43.8,41.8,40.7,39.4,38.9,38.1,31.1$, 30.0, $28.7,27.1,22.0,19.1,18.8,15.4$.

Pyrrolidine 13

To a solution of lactam $12(50 \mathrm{mg}, 0.13 \mathrm{mmol})$ in THF $(4 \mathrm{~mL})$ were added $\mathrm{NaBH}_{4}$ $(20 \mathrm{mg}, 0.53 \mathrm{mmol})$ and $\mathrm{I}_{2}(102 \mathrm{mg}, 0.4 \mathrm{mmol})$. The reaction mixture was refluxed for $8 \mathrm{~h}$, then cooled at $0{ }^{\circ} \mathrm{C}$ and excess hydride quenched with $3 \mathrm{~N} \mathrm{HCl}$ solution, then neutralized and worked up as usual. The crude product was purified by $\mathrm{CC}\left(\mathrm{CH}_{2} \mathrm{Cl}_{2} / \mathrm{MeOH} 90: 10\right)$ giving compound $13(40 \mathrm{mg}, 85 \%)$ as a colorless oil.

Colorless oil. $[\alpha]_{\mathrm{D}}^{20}=-73.6\left(\mathrm{c}=2.74, \mathrm{CHCl}_{3}\right)$. IR $\left(v, \mathrm{~cm}^{-1}\right): 3424,2940,2871,2744,2483$, 1722, 1599. ${ }^{1} \mathrm{H}$ NMR $\left(400 \mathrm{MHz}_{2} \mathrm{CDCl}_{3}\right) \delta(\mathrm{ppm}) 8.46(\mathrm{~s}, 1 \mathrm{H}, \mathrm{NH}) 3.63\left(\mathrm{~s}, 3 \mathrm{H},-\mathrm{CO}_{2} \mathrm{CH}_{3}\right), 3.43$ (bs, 2H, $\left.\mathrm{CH}_{2}-19\right), 2.65$ (s, 1H, CH-13), 1.15 (s, 3H, $\left.\mathrm{CH}_{3}-20\right), 0.81$ (s, 3H, CH-22$), 2.09-0.78$ $(\mathrm{m}, 24 \mathrm{H}) .{ }^{13} \mathrm{C} \mathrm{NMR}\left(100 \mathrm{MHz} \mathrm{CDCl}_{3}\right) \delta(\mathrm{ppm}) 177.9,76.8,56.7,55.7,52.4,51.1,45.7,43.8$, $43.3,42.7,40.7,40.3,39.5,38.5,38.1,33.0,28.6,26.9,22.7,22.1,19.0,18.6,15.3$.

\section{Azide 14}

Azide 11 (50 mg, $0.11 \mathrm{mmol}$ ) was dissolved in $\mathrm{EtOH}$ and treated with $\mathrm{KOH}$ (31.4 mg, $0.56 \mathrm{mmol}$ ) on reflux for $2 \mathrm{~h}$. Then, the reaction mixture was diluted with brine and extracted with $\mathrm{Et}_{2} \mathrm{O}$ and ethereal extract washed with $10 \%$ sol. $\mathrm{H}_{2} \mathrm{SO}_{4}$, sat. sol. $\mathrm{NaHCO}_{3}$, brine and dried over $\mathrm{Na}_{2} \mathrm{SO}_{4}$. The crude product was purified by CC (petroleum ether/EtOAc 90:10), providing the azide 14 as colorless oil (45 $\mathrm{mg}, 98 \%$ ).

Colorless oil. $[\alpha]_{\mathrm{D}}^{20}=-85.6\left(\mathrm{c}=4.50, \mathrm{CHCl}_{3}\right)$. IR $\left(\nu, \mathrm{cm}^{-1}\right): 3855,3668,2942,2098$, $1724,1715,1446,1236,1154,1066,1051,774 .{ }^{1} \mathrm{H} \mathrm{NMR}\left(400 \mathrm{MHz}, \mathrm{CDCl}_{3}\right) \delta_{\mathrm{H}}: 3.64(\mathrm{~s}, 3 \mathrm{H}$, $\left.-\mathrm{CO}_{2} \mathrm{CH}_{3}\right), 2.51\left(\mathrm{t}, \mathrm{J}=7.97 \mathrm{~Hz}, 2 \mathrm{H}, \mathrm{CH}_{2}-17,\right), 1.16\left(\mathrm{~s}, 3 \mathrm{H}, \mathrm{CH}_{3}-20\right), 0.82\left(\mathrm{~s}, 3 \mathrm{H}, \mathrm{CH}_{3}-22\right)$, 2.16-0.99 (m, 23H). ${ }^{13} \mathrm{C}$ NMR $\left(100 \mathrm{MHz}, \mathrm{CDCl}_{3}\right) \delta_{\mathrm{C}}: 178.6,178.0,72.9,56.7,55.8,51.5,51.2$, $44.8,44.3,43.7,41.4,40.6,39.4,38.0,37.7,29.9,29.5,28.7,26.2,22.0,19.0,18.5,15.3$. 
$\mathrm{Et}_{3} \mathrm{~B}$-mediated ATRA of iodoacetonitrile to ent-kaurenoic acid.

ent-Kaurenoic acid 1 (190.0 $\mathrm{mg}, 0.63 \mathrm{mmol})$ in $3.5 \mathrm{~mL}$ EtOH was treated under $\mathrm{N}_{2}$ with iodoacetonitrile $(91 \mu \mathrm{L}, 1.25 \mathrm{mmol}), \mathrm{PhSO}_{2} \mathrm{~N}_{3}\left(345.0 \mathrm{mg}, 1.88 \mathrm{mmol}\right.$ ) and $\mathrm{Et}_{3} \mathrm{~B}$ $(1.9 \mathrm{~mL}, 1.88 \mathrm{mmol})$ at room temperature overnight. The crude product was purified by FC (petroleum ether/EtOAc 90:10) and provided the isomeric mixture 15 (95 mg, 42\%, $\Delta^{15}$ : $\Delta^{16}=45: 55$, NMR data).

Mixture of nitriles 15

IR $\left(v, \mathrm{~cm}^{-1}\right): 3671,2923,2854,2666,1696,1469,1445,1413 .{ }^{1} \mathrm{H}$ NMR $(400 \mathrm{MHz}$, $\mathrm{CDCl}_{3}$ ) selected values, $\delta_{\mathrm{H}}: 5.23(\mathrm{~s}, \mathrm{CH}-15), 5.18-5.14(\mathrm{~m}, \mathrm{CH}-17), 2.98\left(\mathrm{~s}, 2 \times \mathrm{CH}_{2}-18\right), 2.15$ $\left(\mathrm{m}, \mathrm{CH}_{2}-17 \Delta^{15}\right), 1.24,1.23\left(\mathrm{~s}, \mathrm{CH}_{3}-20\right), 0.93,0.95\left(\mathrm{~s}, \mathrm{CH}_{3}-22\right) ;{ }^{13} \mathrm{C} \mathrm{NMR}\left(100 \mathrm{MHz}, \mathrm{CDCl}_{3}\right)$ selected values, $\delta_{C}$ (major $\Delta^{16}$ ): 184.04, 153.35, 118.38, 105.82, 56.99, 54.94, 45.94, 44.02, $41.20,40.67,39.67,39.30,37.75,32.87,28.92,21.79,19.05,18.41,17.04,15.59 ;\left(\operatorname{minor} \Delta^{15}\right)$ : $184.26,142.85,136.04,119.73,56.72,49.22,47.42,43.76,43.40,40.66,39.85,39.26,37.79,28.94$, $25.96,25.32,20.67,19.05,18.95,15.56,15.38$.

$\mathrm{Et}_{3} \mathrm{~B}$-mediated ATRA of iodoacetonitrile to methyl ent-kaurenoate

Methyl ent-kaurenoate $6(180.0 \mathrm{mg}, 0.56 \mathrm{mmol})$ in $3.5 \mathrm{~mL}$ EtOH was treated under $\mathrm{N}_{2}$ with iodoacetonitrile $(82 \mu \mathrm{L}, 1.13 \mathrm{mmol}), \mathrm{PySO}_{2} \mathrm{~N}_{3}(313.0 \mathrm{mg}, 1.7 \mathrm{mmol})$, and $\mathrm{Et}_{3} \mathrm{~B}$ $(1.7 \mathrm{~mL}, 1.7 \mathrm{mmol})$ at room temperature overnight. The crude product was purified by CC (petroleum ether/EtOAc 95:5) and provided the mixture of unsaturated derivatives 16 and 17 (117 mg, 58\%, 16/17 = 3:1, NMR data). This mixture was submitted to a repetitive separation on a silver nitrate impregnated silica column and individual nitriles slightly contaminated with a second isomer were obtained as a colorless oils.

Nitrile 16

Colorless oil. $[\alpha]_{\mathrm{D}}^{20}=-48.8\left(\mathrm{c}=4.6, \mathrm{CHCl}_{3}\right) . \operatorname{IR}\left(\nu, \mathrm{cm}^{-1}\right): 2932,2848,1723,1639,1468$, 1446, 1232, 1158. ${ }^{1} \mathrm{H}$ NMR $\left(400 \mathrm{MHz}_{\mathrm{CDCl}}\right) \delta_{\mathrm{H}}: 5.22(\mathrm{~s}, 1 \mathrm{H}, \mathrm{CH}-15), 3.63\left(\mathrm{~s}, 3 \mathrm{H},-\mathrm{CO}_{2} \mathrm{CH}_{3}\right)$, 2.49-2.38 (m, 2H, CH $2-18), 1.15$ (s, 3H, $\left.\mathrm{CH}_{3}-20\right), 0.99$ (s, 3H, $\left.\mathrm{CH}_{3}-22\right), 2.19-0.78$ (m, 21H). ${ }^{13} \mathrm{C}$ NMR $\left(100 \mathrm{MHz}, \mathrm{CDCl}_{3}\right) \delta_{\mathrm{C}}: 178.0,142.8,136.0,119.8,56.7,51.1,49.2,47.4,43.8,43.8$, $43.4,40.7,39.6,39.3,38.1,28.7,25.9,25.3,20.7,19.1,18.9,15.5,15.2$.

Nitrile 17

Colorless oil. $[\alpha]_{\mathrm{D}}^{20}=-100.8\left(\mathrm{c}=3.4, \mathrm{CHCl}_{3}\right) . \mathrm{IR}\left(v, \mathrm{~cm}^{-1}\right): 2931,2855,1723,1461,1447$, 1150. ${ }^{1} \mathrm{H}$ NMR $\left(400 \mathrm{MHz}, \mathrm{CDCl}_{3}\right) \delta_{\mathrm{H}}: 5.17-5.13(\mathrm{~m}, 1 \mathrm{H}, \mathrm{CH}-17), 3.64\left(\mathrm{~s}, 3 \mathrm{H},-\mathrm{CO}_{2} \mathrm{CH}_{3}\right), 3.04$ (m, 2H, CH $\left.\mathrm{CH}_{2}-18\right), 2.84$ (bs, 1H), 2.21-1.96 (m, 1H), 1.17 (s, 3H, CH -20$), 0.83$ (s, 3H, $\left.\mathrm{CH}_{3}-22\right)$, 2.06-0.79 (m, 19H). ${ }^{13} \mathrm{C}$ NMR $\left(100 \mathrm{MHz} \mathrm{CDCl}_{3}\right) \delta_{\mathrm{C}}: 178.1,152.5,118.9,106.5,57.2,55.1$, 51.3, 49.3, 44.0, 43.8, 41.2, 40.9, 39.7, 39.6, 38.2, 30.8, 29.7, 28.9, 22.1, 19.3, 18.9, 17.2, 15.7 .

DLP-mediated ATRA to methyl $15 \alpha$-hydroxy-ent-kaurenoate

Methyl 15 $\alpha$-hydroxy-ent-kaurenoate 20 (56 mg, $0.17 \mathrm{mmol}$ ) in $3.7 \mathrm{~mL}$ benzene was treated under $\mathrm{N}_{2}$ with ethyl iodoacetate $(60 \mu \mathrm{L}, 0.507 \mathrm{mmol})$ and DLP $(3.4 \mathrm{mg}, 0.009 \mathrm{mmol})$. The reaction was refluxed for $24 \mathrm{~h}$ and after this time the crude product was purified by FC (pentane/EtOAc 95:5), giving a mixture of lactone 22 and ester $E-\mathbf{2 1}(25 \mathrm{mg}, \mathbf{2 2} / E-\mathbf{2 1}=5: 2$ ratio, NMR data). This mixture was acetylated with acetic anhydride $(0.2 \mathrm{~mL}, 2.6 \mathrm{mmol})$ and DMAP $(0.5 \mathrm{~mol} \%)$ in pyridine $(5 \mathrm{~mL})$ at room temperature for $48 \mathrm{~h}$. The crude mixture was extracted with $\mathrm{Et}_{2} \mathrm{O}$, neutralized with $10 \%$ aqueous $\mathrm{H}_{2} \mathrm{SO}_{4}$ and washed with brine. The organic layer was dried, and the solvent was removed under reduced pressure. The crude was purified by column chromatography (pentane/EtOAc 97:3) to afford pure lactone 22 (16 mg, 25\%) and acetate 23 (8 mg, 10\%).

Lactone 22

White solid. M.p. $180-182{ }^{\circ} \mathrm{C}$, from $\mathrm{CH}_{2} \mathrm{Cl}_{2} \cdot[\alpha]_{\mathrm{D}}^{20}=+11.4\left(\mathrm{c}=2.83, \mathrm{CHCl}_{3}\right)$. IR $(v$, $\left.\mathrm{cm}^{-1}\right): 3054,2986,2933,2865,1740,1722 .{ }^{1} \mathrm{H} \mathrm{NMR}\left(400 \mathrm{MHz} \mathrm{CDCl}_{3}\right) \delta_{\mathrm{H}}: 5.81(\mathrm{dt}, J=5.4$, $2.3 \mathrm{~Hz}, 1 \mathrm{H}, \mathrm{CH}-17), 4.48(\mathrm{~d}, J=1.66 \mathrm{~Hz}, 1 \mathrm{H}, \mathrm{CH}-15), 3.64\left(\mathrm{~s}, 3 \mathrm{H},-\mathrm{CO}_{2} \mathrm{CH}_{3}\right), 3.03(\mathrm{~m}, 2 \mathrm{H}$, 
$\left.\mathrm{CH}_{2}-18\right), 2.82$ (bs, 1H, CH-13), 1.19 (s, 3H, $\left.\mathrm{CH}_{3}-20\right), 0.86$ (s, 3H, $\left.\mathrm{CH}_{3}-22\right), 2.20-0.84$ (m, 18H). ${ }^{13} \mathrm{C}$ NMR $\left(100 \mathrm{MHz} \mathrm{CDCl}_{3}\right) \delta_{\mathrm{C}}: 177.9,172.6,148.9,115.3,88.0,56.8,54.6,51.1,46.1,43.8$, $40.8,40.7,39.6,38.4,38.0,34.3,33.1,30.0,28.7,20.7,19.0,18.9,15.7$. GCMS $m / z$ calculated for $\mathrm{C}_{23} \mathrm{H}_{32} \mathrm{O}_{4}$ : 359.28; found $328.2\left(\mathrm{M}^{+}-\mathrm{CO}_{2}\right)$.

Ester 23

Colorless oil. $[\mathrm{a}]_{\mathrm{D}}^{20}=-69.8\left(\mathrm{c}=2.36, \mathrm{CHCl}_{3}\right)$. IR $\left(v, \mathrm{~cm}^{-1}\right): 2984,2930,2859,1727 .{ }^{1} \mathrm{H}$ NMR $\left(400 \mathrm{MHz}, \mathrm{CDCl}_{3}\right) \delta_{\mathrm{H}}: 5.62(\mathrm{t}, J=7.4 \mathrm{~Hz}, 1 \mathrm{H}, \mathrm{CH}-17), 5.44(\mathrm{~s}, 1 \mathrm{H}, \mathrm{CH}-15), 4.12(\mathrm{q}$, $\left.J=7.8,7.3 \mathrm{~Hz}, 2 \mathrm{H},-\mathrm{CO}_{2} \mathrm{CH}_{2} \mathrm{CH}_{3}\right), 3.63\left(\mathrm{~s}, 3 \mathrm{H},-\mathrm{CO}_{2} \mathrm{CH}_{3}\right), 2.97\left(\mathrm{~d}, J=7.1 \mathrm{~Hz}, 2 \mathrm{H}, \mathrm{CH}_{2}-18\right)$, 2.79 (bs, 1H, CH-13), $2.07\left(\mathrm{~s}, 3 \mathrm{H},-\mathrm{O}(\mathrm{CO}) \mathrm{CH}_{3}\right), 1.25\left(\mathrm{t}, \mathrm{J}=7.9 \mathrm{~Hz}, 3 \mathrm{H},-\mathrm{CO}_{2} \mathrm{CH}_{2} \mathrm{CH}_{3}\right), 1.15$ $\left(\mathrm{s}, 3 \mathrm{H}, \mathrm{CH}_{3}-20\right), 0.81\left(\mathrm{~s}, 3 \mathrm{H}, \mathrm{CH}_{3}-22\right), 2.20-0.80(\mathrm{~m}, 18 \mathrm{H}) .{ }^{13} \mathrm{C} \mathrm{NMR}\left(100 \mathrm{MHz}, \overline{\mathrm{CDCl}}_{3}\right) \delta_{\mathrm{C}}$ : 177.9, 171.5, 170.7, 148.7, 117.3, 80.7, 60.6, 56.6, 52.5, 51.1, 47.8, 43.8, 42.3, 40.6, 39.7, 37.9, $37.0,34.7,34.3,33.1,28.6,20.9,20.8,19.1,18.4,15.5,14.2$.

$\mathrm{Bu}_{6} \mathrm{Sn}_{2}$-mediated ATRA to methyl $15 \alpha$-hydroxy-ent-kaurenoate

Methyl 15 $\alpha$-hydroxy-ent-kaurenoate 20 (50 mg, $0.15 \mathrm{mmol}$ ) in $3.2 \mathrm{~mL}$ benzene was treated under $\mathrm{N}_{2}$ with ethyl iodoacetate $(36 \mu \mathrm{L}, 0.3 \mathrm{mmol}), \mathrm{PhSO}_{2} \mathrm{~N}_{3}(83 \mathrm{mg}, 0.45 \mathrm{mmol})$, $\mathrm{Bu}_{6} \mathrm{Sn}_{2}(115 \mu \mathrm{L}, 0.23 \mathrm{mmol})$ and DTBHN $(0.9 \mathrm{mg}, 0.005 \mathrm{mmol})$. The reaction mixture was refluxed for $5 \mathrm{~h}$. The crude product was purified by FC (pentane/EtOAc 95:5) and gave a mixture of compounds 22 and E-21 (43 mg, 22/E-21 = 5:2, NMR data), along with unreacted starting material (5 mg, 10\%).

$\mathrm{Et}_{3} \mathrm{~B}$-mediated ATRA to methyl $15 \alpha$-hydroxy-ent-kaurenoate

Methyl 15 $\alpha$-hydroxy-ent-kaurenoate 20 (50 $\mathrm{mg}, 0.15 \mathrm{mmol})$ in $3.5 \mathrm{~mL}$ EtOH was treated under $\mathrm{N}_{2}$ with ethyl iodoacetate $(36 \mu \mathrm{L}, 0.3 \mathrm{mmol}), \mathrm{PhSO}_{2} \mathrm{~N}_{3}(83 \mathrm{mg}, 0.45 \mathrm{mmol})$ and $\mathrm{Et}_{3} \mathrm{~B}$ $(0.45 \mathrm{~mL}, 0.45 \mathrm{mmol})$ at room temperature overnight. The crude product was purified by column chromatography (pentane/EtOAc 95:5) and afforded unreacted starting material 20 (7 mg, 14\%), ester Z-21 (17 mg, 27\%, contaminated with cca. 20\% E-21), and pure ester E-21 (15 mg, 24\%).

Ester E-21

Colorless oil. $[\alpha]_{\mathrm{D}}^{20}=-89.8\left(\mathrm{c}=4.80, \mathrm{CHCl}_{3}\right) . \mathrm{IR}\left(\nu, \mathrm{cm}^{-1}\right): 3484,2933,2871,1724,1463$, $1447,1370,1329,1233,1191,1153 .{ }^{1} \mathrm{H} \mathrm{NMR}\left(400 \mathrm{MHz}, \mathrm{CDCl}_{3}\right) \delta_{\mathrm{H}}: 5.80(\mathrm{t}, J=7.3 \mathrm{~Hz}, 1 \mathrm{H}$, $\mathrm{CH}-17), 4.13\left(\mathrm{q}, \mathrm{J}=7.1 \mathrm{~Hz}, 2 \mathrm{H},-\mathrm{CO}_{2} \mathrm{CH}_{2} \mathrm{CH}_{3}\right), 3.77(\mathrm{~s}, 1 \mathrm{H}, \mathrm{CH}-15), 3.64\left(\mathrm{~s}, 3 \mathrm{H},-\mathrm{CO}_{2} \mathrm{CH}_{3}\right)$, $3.09\left(\mathrm{~d}, J=7.5 \mathrm{~Hz}, 2 \mathrm{H}, \underline{\mathrm{CH}}_{2}-\mathrm{COOEt}\right), 1.25\left(\mathrm{t}, J=7.1 \mathrm{~Hz}, 3 \mathrm{H},-\mathrm{CO}_{2} \mathrm{CH}_{2} \mathrm{CH}_{3}\right), 1.17(\mathrm{~s}, 3 \mathrm{H}$, $\left.\mathrm{CH}_{3}-20\right), 0.83$ (s, 3H, $\left.\mathrm{CH}_{3}-22\right) 2.85-0.72(\mathrm{~m}, 18 \mathrm{H}) .{ }^{13} \mathrm{C} \mathrm{NMR}\left(100 \mathrm{MHz}, \overline{\mathrm{CDCl}}_{3}\right) \delta_{\mathrm{C}}: 178.11$, 171.90, 153.54, 116.42, 83.18, 60.69, 56.96, 52.89, 51.16, 47.33, 43.82, 40.75, 39.60, 38.02, 36.09, $35.14,35.09,34.65,30.56,28.72,21.03,19.13,18.66,15.64,14.19$.

Ester Z-21

Colorless oil. IR ( $\left.v, \mathrm{~cm}^{-1}\right)$ : 3484, 2932, 2872, 1725, 1464, 1448, 1372, 1312, 1233, 1191, 1155. ${ }^{1} \mathrm{H} \mathrm{NMR}\left(400 \mathrm{MHz}, \mathrm{CDCl}_{3}\right)$ selected values, $\delta_{\mathrm{H}}: 5.50(\mathrm{t}, J=7.8 \mathrm{~Hz}, 1 \mathrm{H}, \mathrm{CH}-17), 4.14$ $\left(\mathrm{q}, \mathrm{J}=7.1 \mathrm{~Hz}, 2 \mathrm{H},-\mathrm{CO}_{2} \mathrm{CH}_{2} \mathrm{CH}_{3}\right), 3.95(\mathrm{~s}, 1 \mathrm{H}, \mathrm{CH}-15), 3.64\left(\mathrm{~s}, 3 \mathrm{H},-\mathrm{CO}_{2} \mathrm{CH}_{3}\right), 3.11-3.32(\mathrm{~m}$,

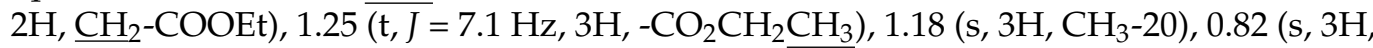
$\left.\mathrm{CH}_{3}-22\right) .{ }^{13} \mathrm{C}$ NMR $\left(100 \mathrm{MHz}, \mathrm{CDCl}_{3}\right)$ selected values, $\delta_{\mathrm{C}}: 178.03,172.79,154.79,115.62$, $80.40,60.96,57.06,53.11,51.05,47.79,43.84,42.13,40.80,39.61,38.06,36.00,35.12,33.18$, $28.69,21.07,19.15,18.27,15.57,14.13$.

$\mathrm{Bu}_{6} \mathrm{Sn}_{2}$-mediated ATRA of iodoacetic acid to methyl $15 \alpha$-hydroxy-ent-kaurenoate

Methyl 15 $\alpha$-hydroxy-ent-kaurenoate $20(64.0 \mathrm{mg}, 0.192 \mathrm{mmol})$ in $2.0 \mathrm{~mL}$ benzene was treated under $\mathrm{N}_{2}$ with iodoacetic acid $(71.4 \mathrm{mg}, 0.38 \mathrm{mmol}), \mathrm{PhSO}_{2} \mathrm{~N}_{3}(105.0 \mathrm{mg}, 0.57 \mathrm{mmol})$, $\mathrm{Bu}_{6} \mathrm{Sn}_{2}(145 \mu \mathrm{L}, 0.28 \mathrm{mmol})$, and DTBHN (1.0 mg, $\left.0.006 \mathrm{mmol}\right)$. The reaction mixture was refluxed for $5 \mathrm{~h}$. The crude product was purified by CC (petroleum ether/EtOAc 70:30) to provide lactone 22 (23 mg, 28\%) and azide 24 as a colorless oil (91 mg, 42\%, contaminated with $\mathrm{PhSO}_{2} \mathrm{~N}_{3}$ ). 


\section{Azide 24}

Colorless oil. IR $\left(v, \mathrm{~cm}^{-1}\right): 3675,2988,2955,2928,2902,2108,1724,1553 .{ }^{1} \mathrm{H}$ NMR $\left(400 \mathrm{MHz}, \mathrm{D}_{3} \mathrm{COD}\right) \delta_{\mathrm{H}}: 3.63\left(\mathrm{~s}, 3 \mathrm{H},-\mathrm{CO}_{2} \mathrm{CH}_{3}\right), 3.52(\mathrm{~s}, 1 \mathrm{H}, \mathrm{CH}-15), 2.46\left(\mathrm{t}, 2 \mathrm{H}, \mathrm{CH}_{2}-17\right)$, $1.17\left(\mathrm{~s}, 3 \mathrm{H}, \mathrm{CH}_{3}-20\right), 0.84\left(\mathrm{~s}, 3 \mathrm{H}, \mathrm{CH}_{3}-22\right), 2.29-0.83(\mathrm{~m}, 21 \mathrm{H}) .{ }^{13} \mathrm{C} \mathrm{NMR}\left(100 \mathrm{MHz}, \mathrm{D}_{3} \mathrm{COD}\right)$ $\delta_{\mathrm{C}}$ : $179.6(2 \times \mathrm{C}(\mathrm{O}) 2), 88.3,76.0,58.1,56.3,51.6,48.5,45.0,43.0,41.8,40.8,39.1,37.1,36.7$, 29.1, 29.0, 28.0, 26.7, 22.3, 20.1, 19.6, 16.0.

$\mathrm{Et}_{3} \mathrm{~B}$-mediated ATRA of iodoacetonitrile to $15 \alpha$-hydroxy-ent-kaurenoic acid

$15 \alpha$-Hydroxy-ent-kaurenoic acid 18 (70 mg, $0.22 \mathrm{mmol})$ in $2.0 \mathrm{~mL} \mathrm{EtOH}$ was treated under $\mathrm{N}_{2}$ with iodoacetonitrile $(32 \mu \mathrm{L}, 0.44 \mathrm{mmol}), \mathrm{PhSO}_{2} \mathrm{~N}_{3}(120 \mathrm{mg}, 0.66 \mathrm{mmol})$, and $\mathrm{Et}_{3} \mathrm{~B}$ $(0.88 \mathrm{~mL}, 0.88 \mathrm{mmol})$. The reaction mixture was purified by $\mathrm{FC}\left(\mathrm{CH}_{2} \mathrm{Cl}_{2} / \mathrm{MeOH} 95: 5\right)$ and provided compound $25\left(48 \mathrm{mg}, 54 \%\right.$ ) as a colorless oil (contaminated with $\mathrm{PhSO}_{2} \mathrm{~N}_{3}$ ).

Nitrile 25

Colorless oil. IR $\left(v, \mathrm{~cm}^{-1}\right)$ : 3836, 3673, 2988, 2973, 2902, 2653, 1698, 1404, 1394, 1381, 1242. ${ }^{1} \mathrm{H}$ NMR $\left(400 \mathrm{MHz}, \mathrm{D}_{3} \mathrm{COD}\right) \delta_{\mathrm{H}}: 5.29(\mathrm{~s}, 1 \mathrm{H}, \mathrm{OH}), 2.71-2.81\left(\mathrm{~m}, 2 \mathrm{H}, \mathrm{CH}_{2}-18\right), 2.54$ (s, 1H, CH-15), $1.24\left(\mathrm{~s}, 3 \mathrm{H}, \mathrm{CH}_{3}-20\right), 0.94\left(\mathrm{~s}, 3 \mathrm{H}, \mathrm{CH}_{3}-22\right), 2.42-0.77(\mathrm{~m}, 21 \mathrm{H}) .{ }^{13} \mathrm{C} \mathrm{NMR}$ $\left(100 \mathrm{MHz}, \mathrm{D}_{3} \mathrm{COD}\right) \delta_{\mathrm{H}}: 183.9,119.4,85.5,83.2,56.4,55.4,53.4,50.3,47.5,43.6,40.5,39.8$, $38.8,37.9,37.6,36.1,28.8,26.4,20.8,19.1,18.8,15.5$.

\section{Azidoester 26}

To a stirred solution of azidoacid $24(45 \mathrm{mg}, 0.10 \mathrm{mmol})$ in approximately $5 \mathrm{~mL}$ of $\mathrm{Et}_{2} \mathrm{O}$ at $0{ }^{\circ} \mathrm{C}$, an etheric solution of $\mathrm{CH}_{2} \mathrm{~N}_{2}$ was added dropwise until the yellow color persisted $(0.2-0.25 \mathrm{mmol})$. The mixture was stirred for $30 \mathrm{~min}$ and concentrated to give the crude product, which was purified by column chromatography (pentane/EtOAc 95:5) to give azidoester $26(41 \mathrm{mg}, 99 \%)$ as a colorless oil.

Colorless oil. $[\alpha]_{\mathrm{D}}^{20}=-55.8\left(\mathrm{c}=2.13, \mathrm{CHCl}_{3}\right)$. IR $\left(v, \mathrm{~cm}^{-1}\right): 3737,3526(\mathrm{w}), 2940,2872$, $2853,2299,2107,1725,1445 .{ }^{1} \mathrm{H}$ NMR $\left(400 \mathrm{MHz}, \mathrm{CDCl}_{3}\right) \delta_{\mathrm{H}}: 3.69\left(\mathrm{~s}, 3 \mathrm{H}, \mathrm{C}-19\left(-\mathrm{CO}_{2} \mathrm{CH}_{3}\right)\right)$, $\left.3.63\left(\mathrm{~s}, 3 \mathrm{H}, \mathrm{C}-21,-\mathrm{CO}_{2} \mathrm{CH}_{3}\right)\right), 3.40(\mathrm{~s}, 1 \mathrm{H}, \mathrm{CH}-15), 2.56\left(\mathrm{t}, J=7.9 \mathrm{~Hz}, 2 \mathrm{H}, \mathrm{CH}_{2}-18\right), 1.16(\mathrm{~s}$, $\left.3 \mathrm{H}, \mathrm{CH}_{3}-20\right), 0.81\left(\mathrm{~s}, 3 \mathrm{H}, \mathrm{CH}_{3}-22\right), 2.16-0.78(\mathrm{~m}, 21 \mathrm{H}) .{ }^{13} \mathrm{C} \mathrm{NMR}\left(100 \mathrm{MHz}, \mathrm{CDCl}_{3}\right) \delta_{\mathrm{C}}$ : $177.84,173.61,85.22,75.44,56.71,54.72,51.71,51.06,47.55,43.78,41.87,40.59,39.59,37.98$, $36.05,35.66,29.41,28.63,28.41,25.78,21.03,18.99,18.19,15.34$.

\section{Lactam 27}

A solution of azidoester 26 (53 mg, $0.12 \mathrm{mmol})$ and $10 \% \mathrm{Pd} / \mathrm{C}(10 \% w / w)$ in dry EtOAc $(2 \mathrm{~mL})$ was stirred for $64 \mathrm{~h}$ at room temperature under $\mathrm{H}_{2}(1 \mathrm{~atm})$. The catalyst was filtered off, the solvent was removed under reduced pressure, and the crude purified by $\mathrm{FC}\left(\mathrm{CH}_{2} \mathrm{Cl}_{2} / \mathrm{MeOH} 85: 15\right)$, giving lactam $27(16 \mathrm{mg}, 35 \%)$ as a yellowish oil.

Yellowish oil. $[\alpha]_{\mathrm{D}}^{20}=-90.8\left(\mathrm{c}=3.0, \mathrm{CHCl}_{3}\right)$. IR $\left(\nu, \mathrm{cm}^{-1}\right): 3351,2933,2871,2322,1722$, 1685, 1552. ${ }^{1} \mathrm{H}$ NMR $\left(400 \mathrm{MHz}, \mathrm{CDCl}_{3}\right) \delta_{\mathrm{H}}: 6.73(\mathrm{~s}, 1 \mathrm{H}, \mathrm{NH}), 3.63\left(\mathrm{~s}, 3 \mathrm{H},-\mathrm{CO}_{2} \mathrm{CH}_{3}\right), 3.49(\mathrm{~s}$, $1 \mathrm{H}, \mathrm{CH}-15), 2.44-2.27(\mathrm{~m}, 2 \mathrm{H}), 1.16\left(\mathrm{~s}, 3 \mathrm{H}, \mathrm{CH}_{3}-20\right), 0.81\left(\mathrm{~s}, 3 \mathrm{H}, \mathrm{CH}_{3}-22\right), 2.14-0.79(\mathrm{~m}, 21 \mathrm{H})$. ${ }^{13} \mathrm{C}$ NMR $\left(100 \mathrm{MHz}, \mathrm{CDCl}_{3}\right) \delta_{\mathrm{C}}: 179.1,178.0,88.2,70.8,56.8,54.4,51.1,47.4,44.9,43.7,40.7$, $38.0,39.6,36.6,35.4,30.6,29.3,28.6,26.3,21.2,19.1,19.0,15.5$.

\section{Conclusions}

Modifications of ent-kaurenoic acid derivatives at the exo-methylenic double bond of the tetracyclic diterpenic framework based on mild radical mediated $\mathrm{C}-\mathrm{C}$ bond forming reactions such as the iodine ATRA and the azidoalkylation reaction have been performed. Although this reaction has been demonstrated previously on other substrates, their application in complex natural compounds is not well documented and far from trivial due to the potential side reactions such as intramolecular hydrogen atom transfers. Both steric and electronic factors strongly influence the outcome of the free radical sequences, providing unprecedented avenues for expanding structural diversity of natural products.

The azidoalkylation reaction proved to be extremely useful in the context of increasing structural complexity of the parent natural scaffold, including simultaneous functional- 
ization with different heteroatomic functional groups. The advantage of the tertiary azide moiety was demonstrated by subsequent reductions, leading to spiro-fused lactam and pyrrolidine fragments. The reported structural modifications led to a series of new compounds with relevant biological activity, which was demonstrated by in vitro cytotoxicity tests on several tumor cell lines. The hybrid terpene-nitrogen containing heterocycles with unprecedented spiro-junction have shown relevant cytotoxicity and promising selectivity indexes. These results represent a solid basis for following research on the synthesis of such derivatives based on available natural product templates.

Supplementary Materials: The following are available online. X-ray crystal structure report for lactam 12 (CCDC 2023783), X-ray crystal structure report for lactone 22 (CCDC 2023785), IR and NMR spectra of compounds 11, 12, 13, 16, 22, 25, 26, 27, $\mathrm{IC}_{50}$, and SI data for investigated entkauranic derivatives.

Author Contributions: Conceptualization, supervision and funding acquisition, P.R. and V.K.; preparation of substrates and chemical synthesis, N.U., E.P. and V.G.; evaluation of cytotoxicity, L.P. and D.D.; writing—original draft preparation, V.K.; writing—review and editing, P.R. All authors have read and agreed to the published version of the manuscript.

Funding: This research was funded by the SCOPES program of the Swiss National Science Foundation, project IZ73Z0_152346/1; the Swiss National Science Foundation, projects 200020_172621 and 200020_201092; and the National Agency for Research and Development (ANCD) of the Republic of Moldova, grant number 20.80009.8007.03.

Institutional Review Board Statement: Not applicable.

Informed Consent Statement: Not applicable.

Data Availability Statement: Data of the compounds are available on request from the corresponding authors.

Acknowledgments: The X-ray crystal structure determination service unit of the Department of Chemistry, Biochemistry, and Pharmaceutical Sciences of the University of Bern (P. Macchi and J. Hauser) is acknowledged for measuring, solving, refining, and summarizing the structures of compounds 12 and 22.

Conflicts of Interest: The authors declare no conflict of interest.

Sample Availability: Samples of the compounds are available on request from the corresponding authors.

\section{References}

1. Hanson, J.R.; Oliveira, B.H.D. Stevioside and Related Sweet Diterpenoid Glycosides. Nat. Prod. Rep. 1993, 10, 301-309. [CrossRef]

2. Ghisalberti, E.L. The Biological Activity of Naturally Occurring Kaurane Diterpenes. Fitoterapia 1997, 68, 303-325.

3. Kataev, E.; Khaybullin, R.N.; Sharipova, R.R.; Strobykina, I.Y. Ent-Kaurane Diterpenoids and Glycosides: Isolation, Properties, and Chemical Transformations. Rev. J. Chem. 2011, 1, 93-160. [CrossRef]

4. Villa-Ruano, N.; Lozoya-Gloria, E.; Pacheco-Hernández, Y. Kaurenoic Acid. In Studies in Natural Products Chemistry; Elsevier: Amsterdam, The Netherlands, 2016; Volume 51, pp. 151-174. ISBN 978-0-444-63932-5.

5. Wang, L.; Li, D.; Wang, C.; Zhang, Y.; Xu, J. Recent Progress in the Development of Natural Ent-Kaurane Diterpenoids with Anti-Tumor Activity. Mini Rev. Med. Chem. 2011, 11, 910-919. [CrossRef]

6. Hutt, O.E.; Doan, T.L.; Georg, G.I. Synthesis of Skeletally Diverse and Stereochemically Complex Library Templates Derived from Isosteviol and Steviol. Org. Lett. 2013, 15, 1602-1605. [CrossRef]

7. Lohoelter, C.; Weckbecker, M.; Waldvogel, S.R. (-)-Isosteviol as a Versatile Ex-Chiral-Pool Building Block for Organic Chemistry: (-)-Isosteviol as a Building Block for Organic Chemistry. Eur. J. Org. Chem. 2013, 2013, 5539-5554. [CrossRef]

8. Peixoto, A.F.; de Melo, D.S.; Fernandes, T.F.; Fonseca, Y.; Gusevskaya, E.V.; Silva, A.M.S.; Contreras, R.R.; Reyes, M.; Usubillaga, A.; dos Santos, E.N.; et al. Rhodium Catalyzed Hydroformylation of Kaurane Derivatives: A Route to New Diterpenes with Potential Bioactivity. Appl. Catal. Gen. 2008, 340, 212-219. [CrossRef]

9. Hueso-Falcón, I.; Girón, N.; Velasco, P.; Amaro-Luis, J.M.; Ravelo, A.G.; de las Heras, B.; Hortelano, S.; Estevez-Braun, A. Synthesis and Induction of Apoptosis Signaling Pathway of Ent-Kaurane Derivatives. Bioorg. Med. Chem. 2010, 18, 1724-1735. [CrossRef] [PubMed]

10. Qiu, Y.; Gao, S. Trends in Applying C-H Oxidation to the Total Synthesis of Natural Products. Nat. Prod. Rep. 2016, 33, 562-581. [CrossRef] [PubMed] 
11. Shugrue, C.R.; Miller, S.J. Applications of Nonenzymatic Catalysts to the Alteration of Natural Products. Chem. Rev. 2017, 117, 11894-11951. [CrossRef]

12. Stateman, L.; Nakafuku, K.; Nagib, D. Remote C-H Functionalization via Selective Hydrogen Atom Transfer. Synthesis 2018, 50, 1569-1586. [CrossRef]

13. Kharasch, M.S.; Jensen, E.V.; Urry, W.H. Addition of Carbon Tetrachloride and Chloroform to Olefins. Science 1945, $102,128$. [CrossRef]

14. Kharasch, M.S.; Urry, W.H.; Jensen, E.V. Addition of Derivatives of Chlorinated Acetic Acids to Olefins. J. Am. Chem. Soc. 1945, 67, 1626. [CrossRef]

15. Kharasch, M.S.; Skell, P.S.; Fisher, P. Reactions of Atoms and Free Radicals in Solution. XII. The Addition of Bromo Esters to Olefins. J. Am. Chem. Soc. 1948, 70, 1055-1059. [CrossRef]

16. Byers, Jeffrey Atom Transfer Reactions. In Radicals in Organic Synthesis; Renaud, P.; Sibi, M.P. (Eds.) Wiley-VCH Verlag GmbH: Weinheim, Germany, 2001; Volume 1, pp. 72-89. ISBN 3-527-301 60-7.

17. Pintauer, T.; Matyjaszewski, K. Atom Transfer Radical Addition and Polymerization Reactions Catalyzed by PPM Amounts of Copper Complexes. Chem. Soc. Rev. 2008, 37, 1087. [CrossRef] [PubMed]

18. Meyer, D.; Vin, E.; Wyler, B.; Lapointe, G.; Renaud, P. Facile Preparation of Functionalized 1-Substituted Cycloalkenes via an Iodine Atom Transfer Radical Addition-Elimination Process. Synlett 2016, 27, 745-748. [CrossRef]

19. Tappin, N.D.C.; Renaud, P. Methyl Radical Initiated Kharasch and Related Reactions. Adv. Synth. Catal. 2021, 363, $275-282$. [CrossRef]

20. Renaud, P.; Ollivier, C.; Panchaud, P.; Panchaud, P. Radical Carboazidation of Alkenes: An Efficient Tool for the Preparation of Pyrrolidinone Derivatives. Angew. Chem. Int. Ed. Engl. 2002, 41, 3460-3462. [CrossRef]

21. Panchaud, P.; Chabaud, L.; Landais, Y.; Ollivier, C.; Renaud, P.; Zigmantas, S. Radical Amination with Sulfonyl Azides: A Powerful Method for the Formation of CN Bonds. Chem. Eur. J. 2004, 10, 3606-3614. [CrossRef]

22. Lapointe, G.; Kapat, A.; Weidner, K.; Renaud, P. Radical Azidation Reactions and Their Application in the Synthesis of Alkaloids. Pure Appl. Chem 2012, 84, 1633-1641. [CrossRef]

23. Panchaud, P.; Ollivier, C.; Renaud, P.; Zigmantas, S. Radical Carboazidation: Expedient Assembly of the Core Structure of Various Alkaloid Families. J. Org. Chem. 2004, 69, 2755-2759. [CrossRef] [PubMed]

24. Weidner, K.; Giroult, A.; Panchaud, P.; Renaud, P. Efficient Carboazidation of Alkenes Using a Radical Desulfonylative Azide Transfer Process. J. Am. Chem. Soc. 2010, 132, 17511-17515. [CrossRef]

25. Cren, S.; Schär, P.; Renaud, P.; Schenk, K. Diastereoselectivity Control of the Radical Carboazidation of Substituted Methylenecyclohexanes. J. Org. Chem. 2009, 74, 2942-2946. [CrossRef]

26. Torres, A.; Molinillo, J.M.G.; Varela, R.M.; Casas, L.; Mantell, C.; Martínez de la Ossa, E.J.; Macías, F.A. Helikaurolides A-D with a Diterpene-Sesquiterpene Skeleton from Supercritical Fluid Extracts of Helianthus annuus L. Var. Arianna. Org. Lett. 2015, 17, 4730-4733. [CrossRef] [PubMed]

27. Ollivier, C.; Bark, T.; Renaud, P. An Efficient and Practical Tin Free Procedure for Radical Iodine Atom-Transfer Reactions. Synthesis 2000, 2000, 1598-1602. [CrossRef]

28. Ollivier, C.; Renaud, P. A Novel Approach for the Formation of Carbon-Nitrogen Bonds: Azidation of Alkyl Radicals with Sulfonyl Azides. J. Am. Chem. Soc. 2001, 123, 4717-4727. [CrossRef] [PubMed]

29. Bräse, S.; Gil, C.; Knepper, K.; Zimmermann, V. Organic Azides: An Exploding Diversity of a Unique Class of Compounds. Angew. Chem. Int. Ed. 2005, 44, 5188-5240. [CrossRef]

30. Agalave, S.G.; Maujan, S.R.; Pore, V.S. Click Chemistry: 1,2,3-Triazoles as Pharmacophores. Chem. Asian J. 2011, 6, $2696-2718$. [CrossRef]

31. Panchaud, P.; Renaud, P. A Convenient Tin-Free Procedure for Radical Carboazidation and Azidation. J. Org. Chem. 2004, 69, 3205-3207. [CrossRef]

32. Panchaud, P.; Renaud, P. Tin-Free Radical Carboazidation. Chim. Int. J. Chem. 2004, 58, 232-233. [CrossRef]

33. Brown, H.C.; Hebert, N.C. Organoboranes: XXXIII. Protonolysis of Triethylborane with Carboxylic Acids. J. Organomet. Chem. 1983, 255, 135-141. [CrossRef]

34. Suzuki, A. Organoboranes in Organic Syntheses Including Suzuki Coupling Reaction. Heterocycles 2010, 80, 15-43. [CrossRef]

35. Harish, V.; Periasamy, M. Enantiomerically Pure Piperazines via NaBH4/I2 Reduction of Cyclic Amides. Tetrahedron Asymmetry 2017, 28, 175-180. [CrossRef]

36. CCDC 2023783 and 2023785 Contain the Supplementary Crystallographic Data for Compound 12 and 22. Available online: http:/ / www.Ccdc.Cam.Ac.Uk. (accessed on 23 July 2021).

37. Curran, D.P.; Bosch, E.; Kaplan, J.; Newcomb, M. Rate Constants for Halogen Atom Transfer from Representative.Alpha.-Halo Carbonyl Compounds to Primary Alkyl Radicals. J. Org. Chem. 1989, 54, 1826-1831. [CrossRef]

38. Badisa, R.B.; Darling-Reed, S.F.; Joseph, P.; Cooperwood, J.S.; Latinwo, L.M.; Goodman, C.B. Selective Cytotoxic Activities of Two Novel Synthetic Drugs on Human Breast Carcinoma MCF-7 Cells. Anticancer Res. 2009, 29, 2993-2996.

39. Genomics of Drug Sensitivity in Cancer. Available online: https:/ / www.cancerrxgene.org (accessed on 30 July 2020).

40. Saldívar-González, F.I.; Lenci, E.; Trabocchi, A.; Medina-Franco, J.L. Exploring the Chemical Space and the Bioactivity Profile of Lactams: A Chemoinformatic Study. RSC Adv. 2019, 9, 27105-27116. [CrossRef] 
41. Caruano, J.; Muccioli, G.G.; Robiette, R. Biologically Active $\gamma$-Lactams: Synthesis and Natural Sources. Org. Biomol. Chem. 2016, 14, 10134-10156. [CrossRef]

42. CrysAlisPro (Version 1.171.34.44); Oxford Diffraction Ltd.: Yarnton, UK, 2010.

43. Macchi, P.; Bürgi, H.-B.; Chimpri, A.S.; Hauser, J.; Gál, Z. Low-Energy Contamination of Mo Microsource X-Ray Radiation: Analysis and Solution of the Problem. J. Appl. Crystallogr. 2011, 44, 763-771. [CrossRef]

44. Sheldrick, G.M. SHELXT_-Integrated Space-Group and Crystal-Structure Determination. Acta Crystallogr. Sect. Found. Adv. 2015, 71, 3-8. [CrossRef]

45. Sheldrick, G.M. Crystal Structure Refinement with SHELXL. Acta Crystallogr. Sect. C Struct. Chem. 2015, 71, 3-8. [CrossRef] [PubMed]

46. Dolomanov, O.V.; Bourhis, L.J.; Gildea, R.J.; Howard, J.A.K.; Puschmann, H. OLEX2: A Complete Structure Solution, Refinement and Analysis Program. J. Appl. Crystallogr. 2009, 42, 339-341. [CrossRef] 